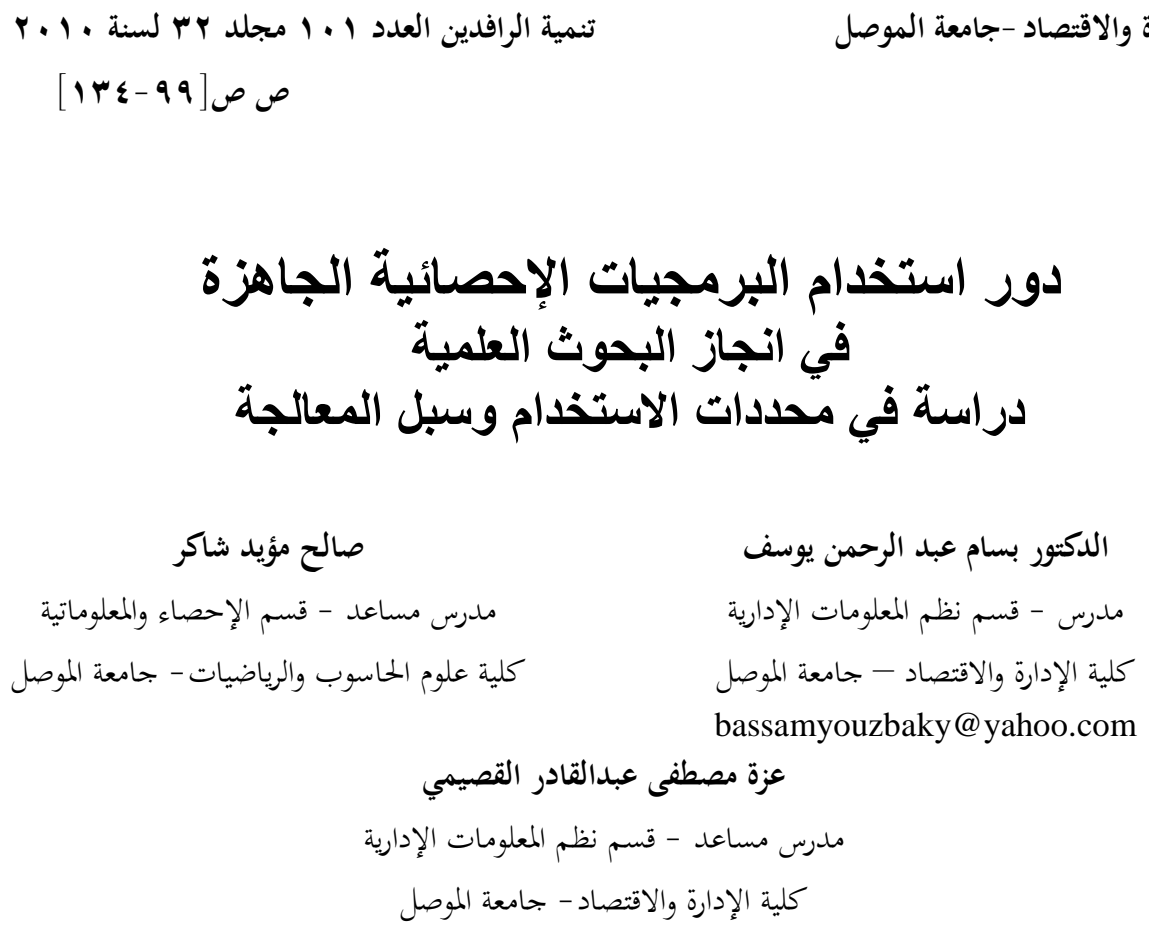




\title{
Role of Using Ready-made Statistical Software in the Completion of Scientific Researches
}

\author{
Bassam A. Yousif (PhD) \\ Lecturer \\ Department of Management \\ Information Systems \\ University of Mosul
}

\author{
Saleh M. Shaker \\ Assistant Lecturer \\ Department of Statistics and \\ Information \\ University of Mosul
}

\author{
Azza M. Abdul Kadir \\ Assistant Lecturer \\ Department of Management \\ Information Systems \\ University of Mosul
}

\begin{abstract}
The current study sought to identify the nature of using statistical software analyses in the completion of scientific researches in a simple random sample of theses. This done through content analysis of twenty-nine Master in Business Administration, and has been to identify a set of statistical analysis to be adopted before and after data collection in these theses. A theoretical framework has been demonstrated for identification, while the practical aspect has been validated to use the standard methods through the statement. They are within the three phases; first phase consisted procedures prior to use statistical analysis software in ready-choice sample size, and the second phase was the use of statistical analysis as regression and correlation. The third was the last phase and the subsequent actions of the methods used in interpreting the output of statistical software. A set of results is perhaps the most prominent was the low level of scientific use of statistical methods by the researchers. It was proposed also that the need for attention by researchers to verify the existence of overlap between the variables and linear. The identification of the extent is penetrated by the direction of the relationship between predictive variables and changing according to the adopted theoretical frameworks, and hence it is one of the most prominent indicators of the presence of interference in writing.
\end{abstract}

Key words: Statistical Software, Scientific Research, Statistical Analysis.

المقدمة

تعد البرمجيات الإحصائية من تقنيات المعلومـات التي تستخدم في تتفيذ المعالجـات

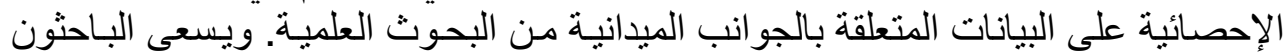

على اختلاف تخصصاتهم لاستخدام هذه التقنيات لما تمتاز بهاه، من سـر عة كبيرة في إجراء التهاء

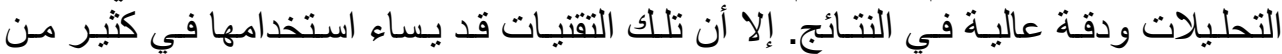

الأحيـان، لأسـباب قد تعـود إلـى انخفـاض مستوى التأصسيل العلمسي للجوانـب الإحصـائية،

وتحديداً من غير المختصبن في العلوم الإحصائية.

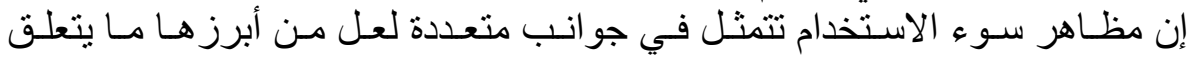

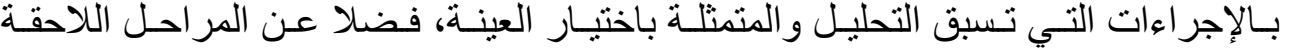

و المتمثلة بتفسير الاعزئ النتائج.

مشكبة البحث

إن مسكلة البحـث تتمثل بلجوء الباحثين لاسـتخدام البرمجيـات الإحصائية مـن دون

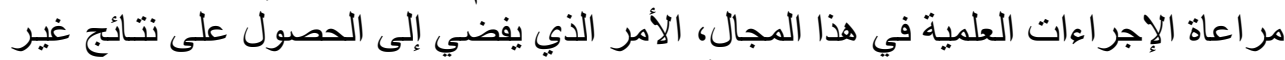

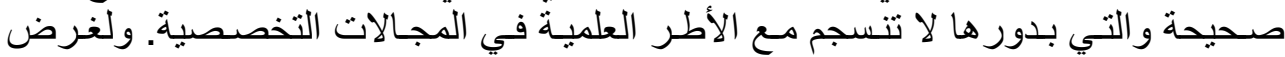

الوقوف على طبيعة المشكلة، فقد تم صباغة التساؤ لات الآتية: 
يوسف وشاكر والقصيمي[ [- 1.

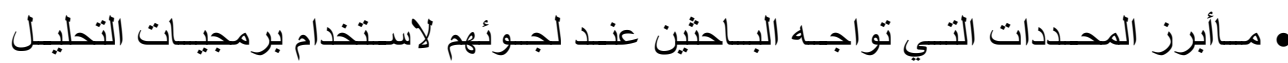

الإحصائي؟

هـ هل تتسم نتائج التحليلات الإحصائية، في البحوث العلمية، بمستوى عالٍ من الدقة؟

1. فرضية البحث مستوى الاهتمام بالسبل الإحصائية العلمية من قبل الباحثين في إنجاز بحوثهم r. . إن انخفاض قدرة الباحثين في التعامل مع تللك التقنيات يؤدي إلى ظهور الإخفاقات في

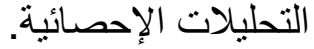

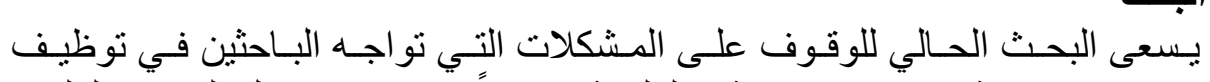

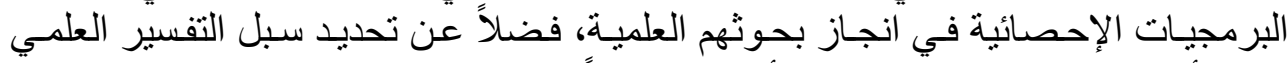
لنتائج أبرز العمليات الإحصائية، و الأكثر استخداماً.

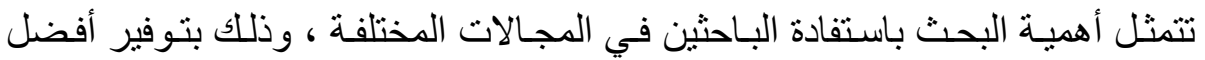
أهمية البحث

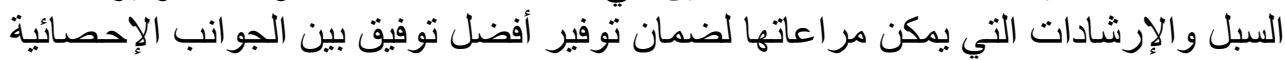
من جانب، و التقنيات البرمجية من جانب آخر.

يتمثل منهج البحث، بتحليل مضمون عينة عثوائية من الرسائل الجامعية المنجزة في قسم إدارة الأعمال، وذللك لغرض التحقق من وجود المشكلة، على نحو يشكل ظاهرة فئي الجئي

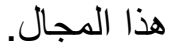

الإطار النظري للبحث

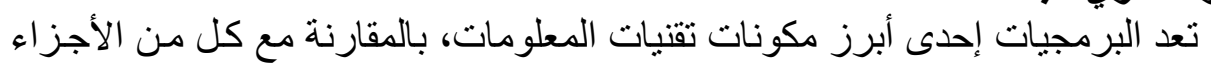

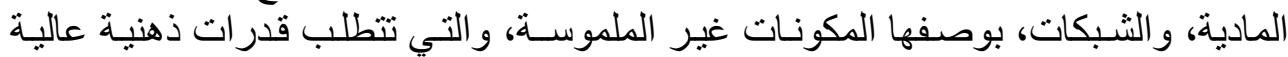

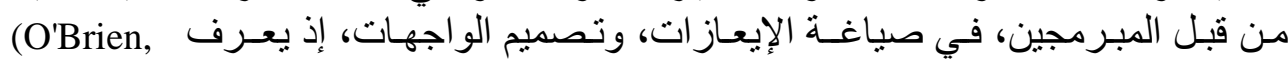

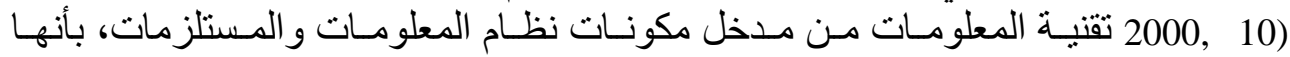

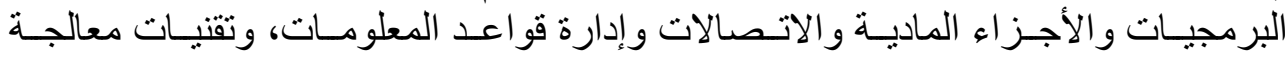

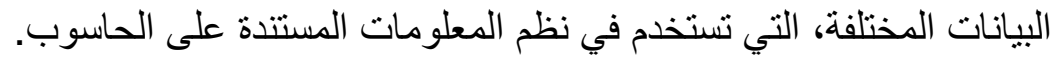

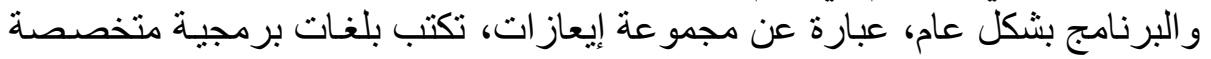

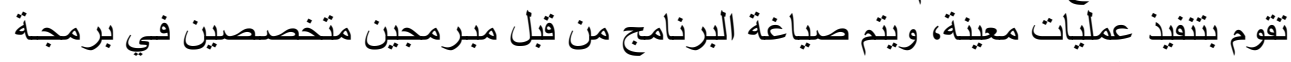

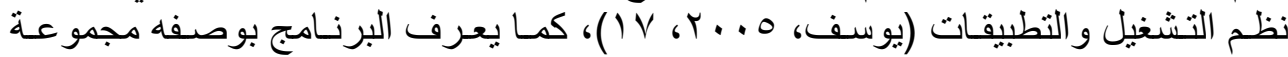

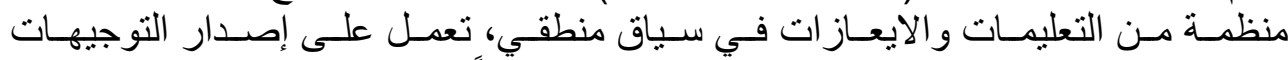

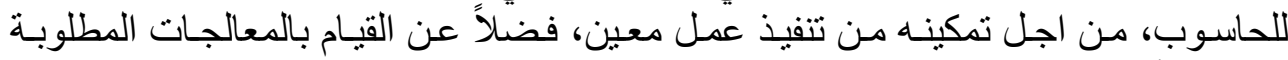

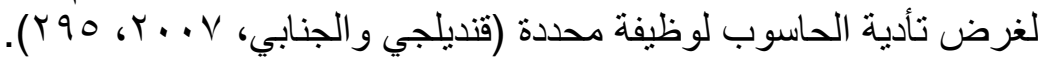


ويمكن تقسيم البرمجيات على فئتين عامتين هما: برمجيات النظم، وهي قد تمثل الفئة

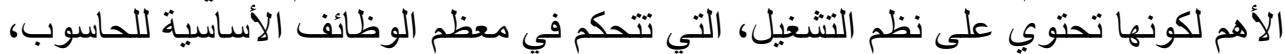

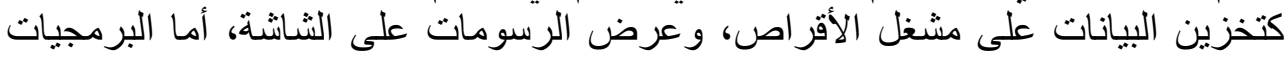

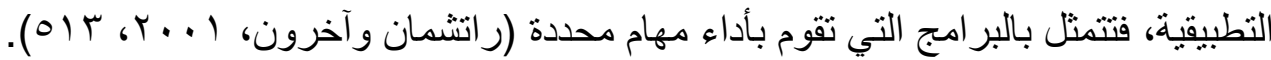

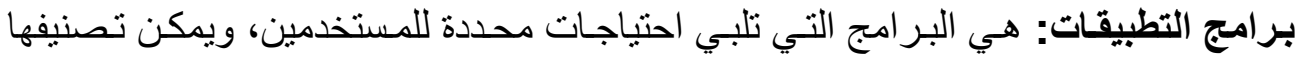

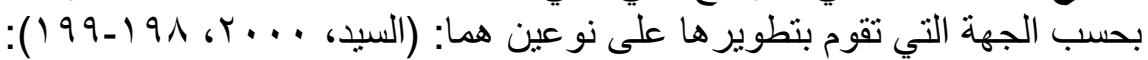

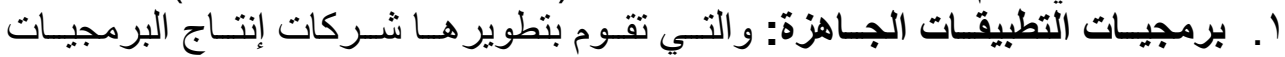

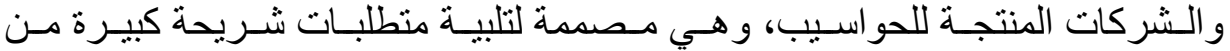

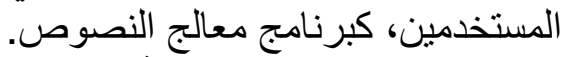

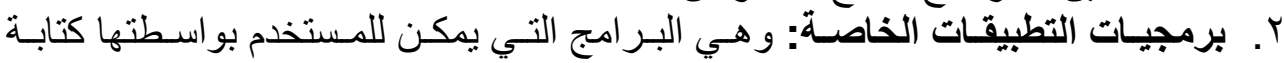

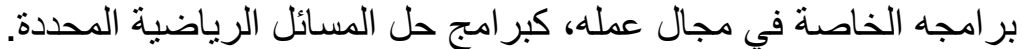

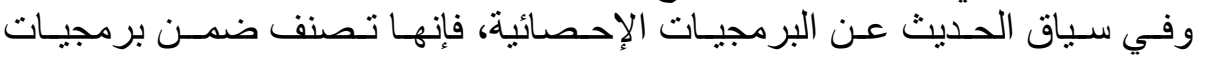

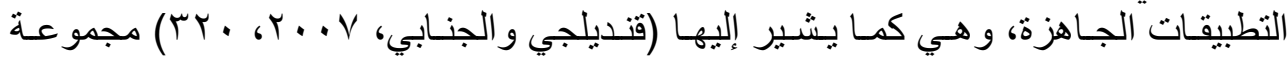
بر امج متخصصة لأغر اض وتطبيقات محددة، تصمم من قبل المبرمجين، لتناسب أنشطة منماثلة في عدد من المؤسسات.

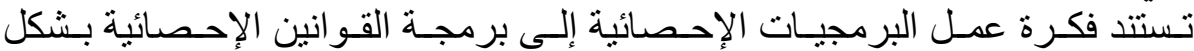

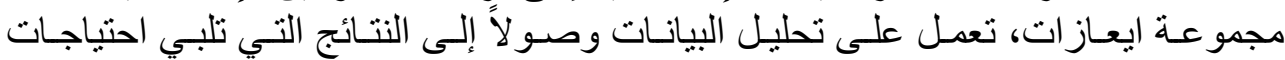

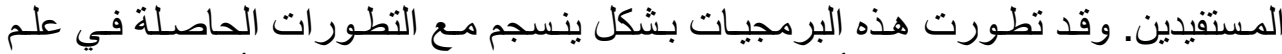

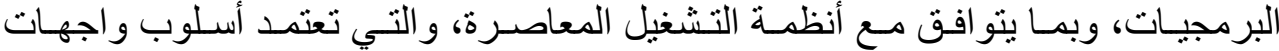

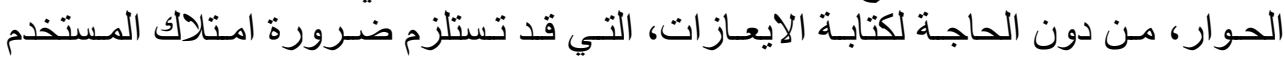

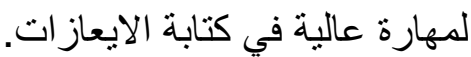

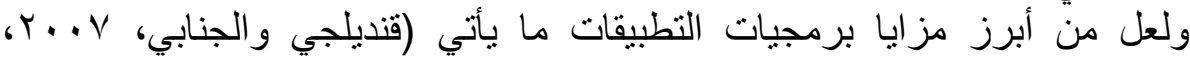

! . تحقيق وفورات في الوقت و الجهد المستغرق في عمليات البرمجة واختبار الأنظمة.

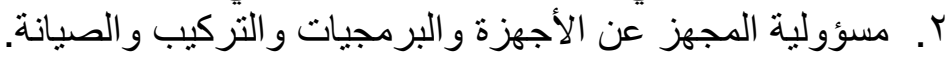

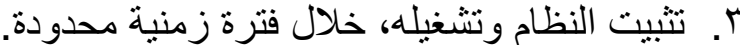
ع. . إمكانية تدريب الموظفين من قبل الثركة المتعاقد معها على عمليات التهات التشغيل.

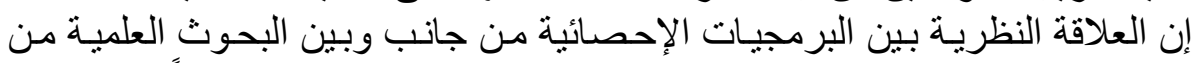

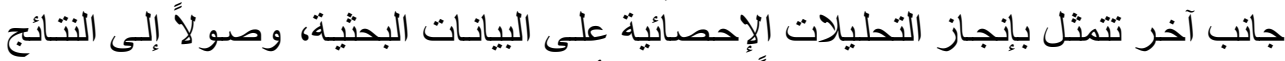

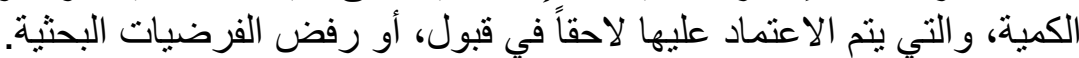

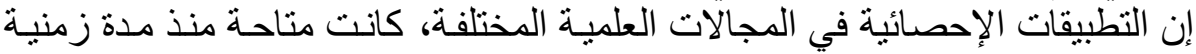

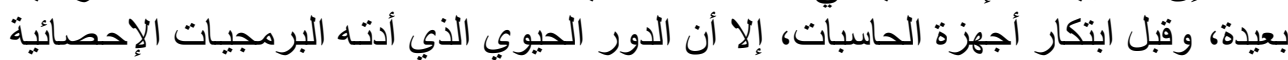

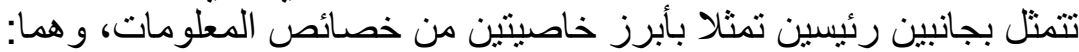

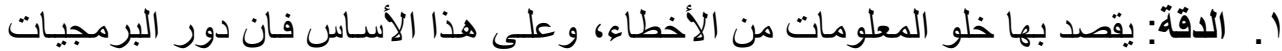

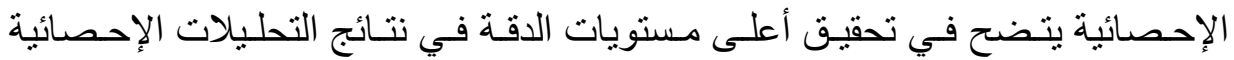
للبيانات الخاصة بالبحوث العلمية. 
يوسف وشاكر والقصيمي[ [ [1]

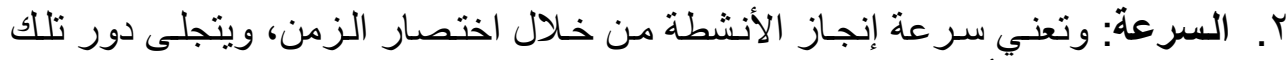

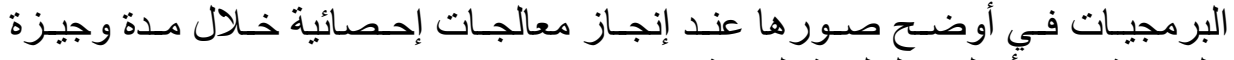
بالمقارنة مع الأساليب التقليدية اليدوية.

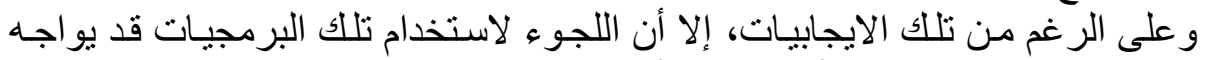

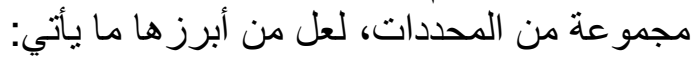
ا . . محددات تتعلق بالمعالجات السابقة، كاختيار حجم العينة العينة، و عائديـة البيانـات إلى التوزيع الطبيعي. r. محددات تتمثنل باستخدام إيعـاز ات إحصائية لا تتسجم مـع طبيعـة البيانـات، كاستخدام

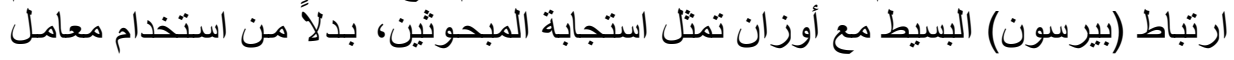
ارنباط الرتب (سبيرمان).

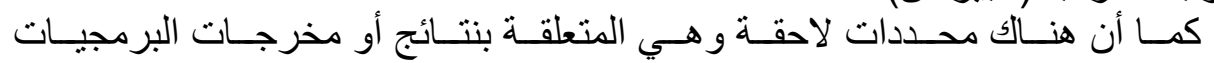

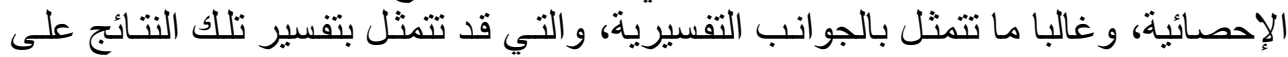

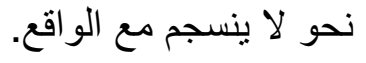

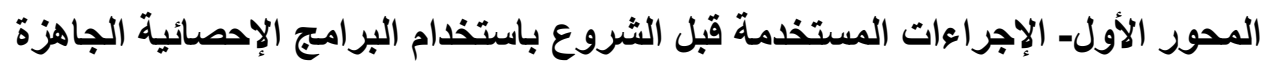

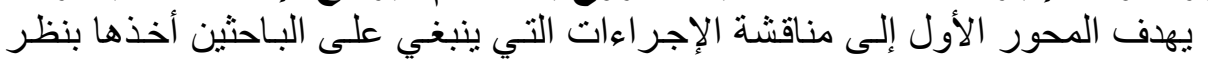
الاعتبار قبل الثروع باستخدام البرمجيات الإحصائية وعلى النحو الآني:

أولاً- تحديد أسلوب اختيار العينة

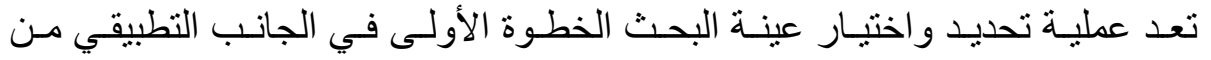

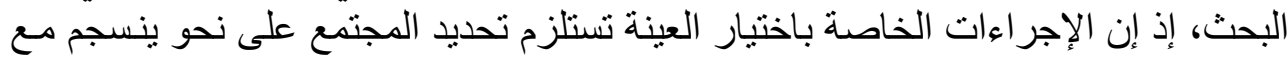

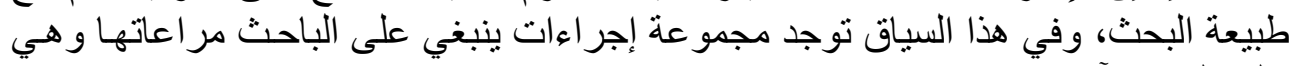
على النحو الآتي:

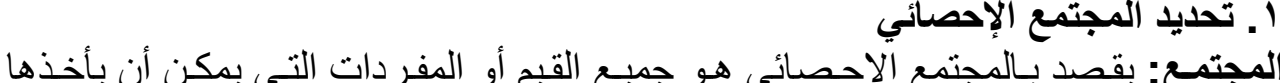

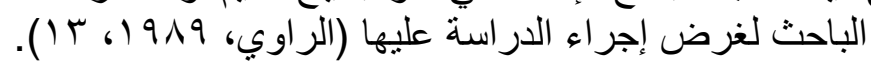

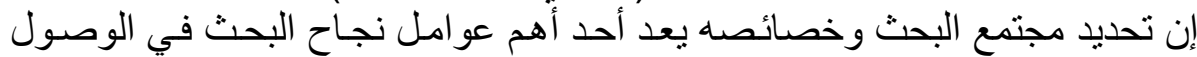

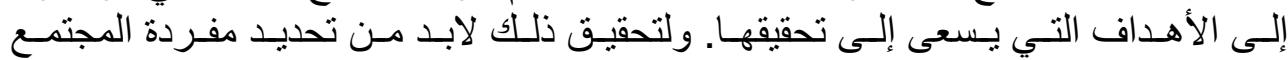

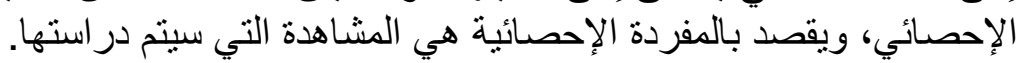
r. تحديد مفردة المجتمع

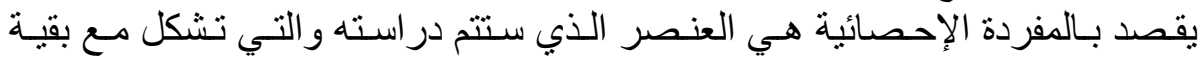

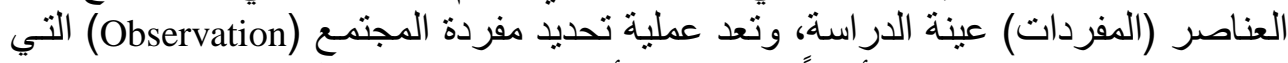

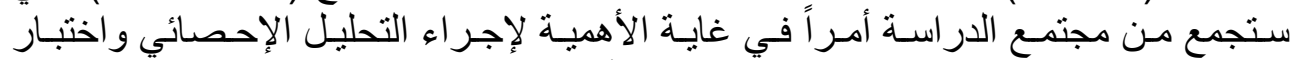

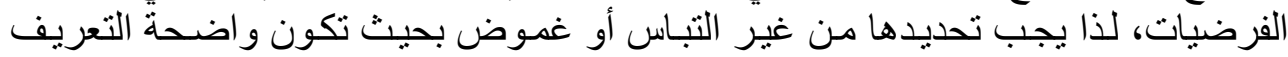

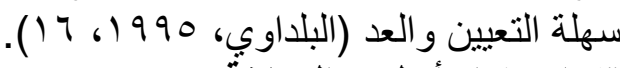
r. استخدام أسلوب المعاينة

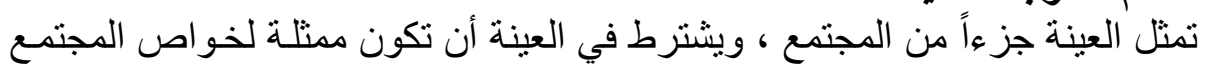

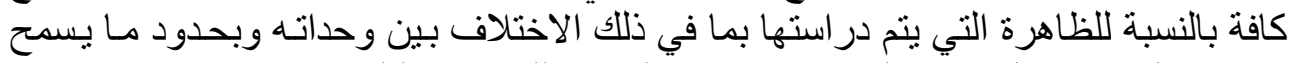

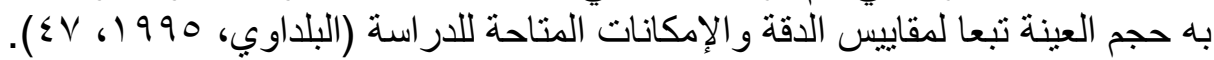




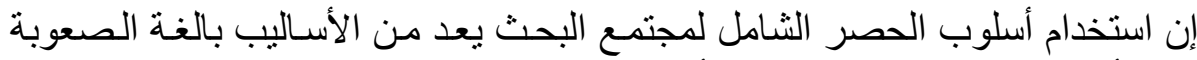

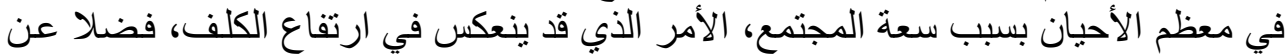

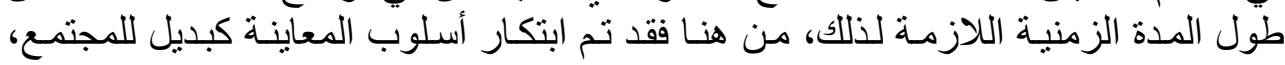

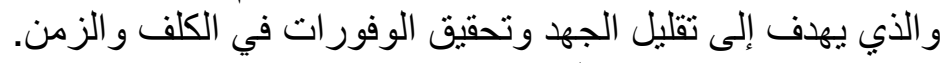
ويمكن تحديد نو عين من العينات:

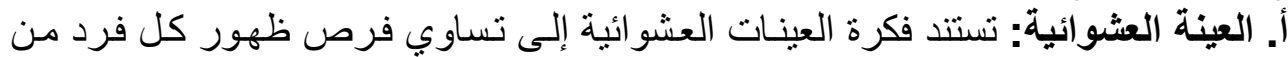

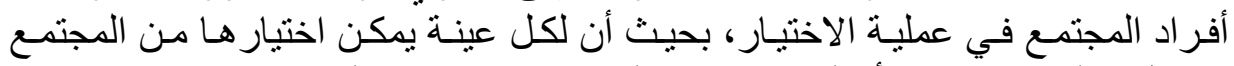

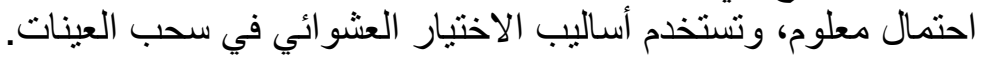

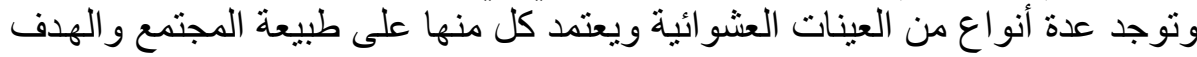
من الار اسة والإمكانات المناحة.

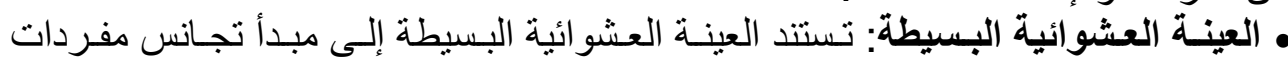

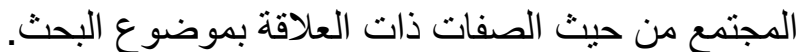

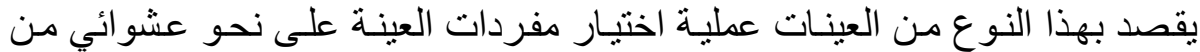

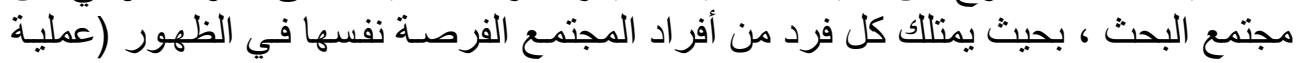

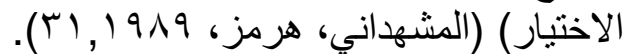

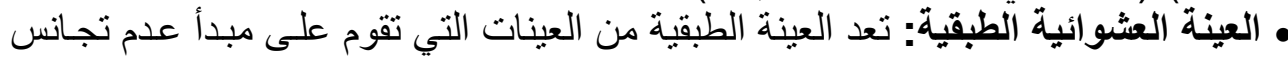

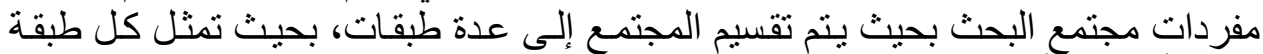
مجتمعاً متجانساً بحد ذاته.

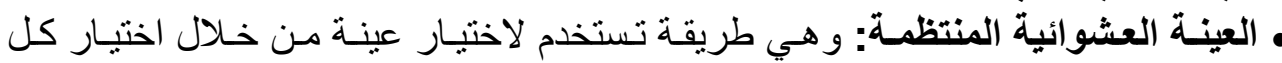

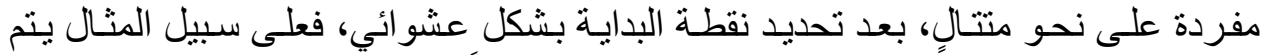

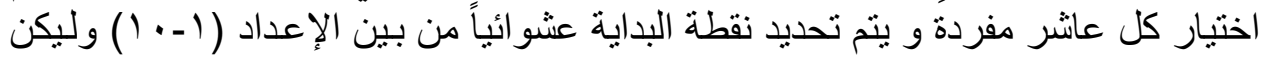

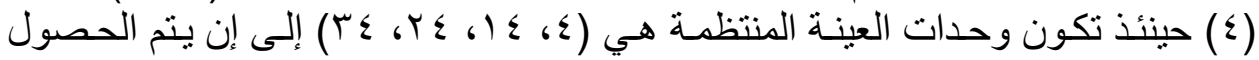
على وحدات العينة المطلوبة.

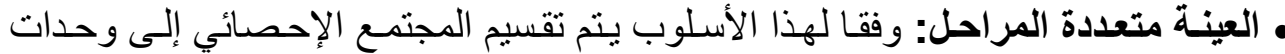

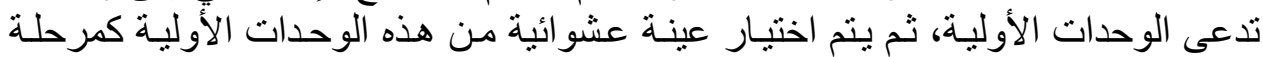

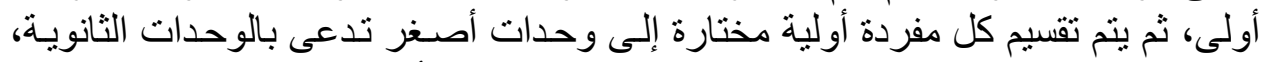

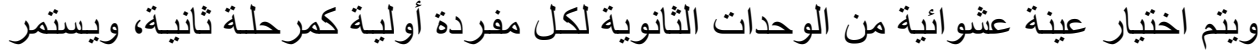

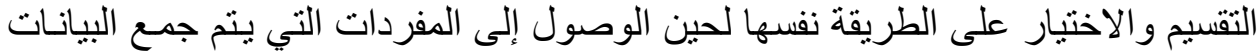

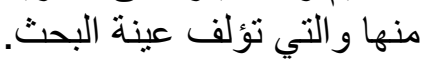
ب. العينات غير العشوائية

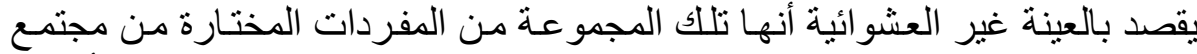

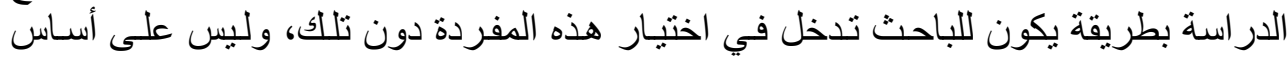

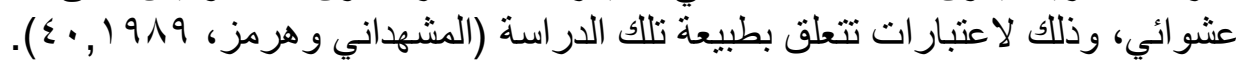
وتتقسم العينات غير العشوائية على نوعين:

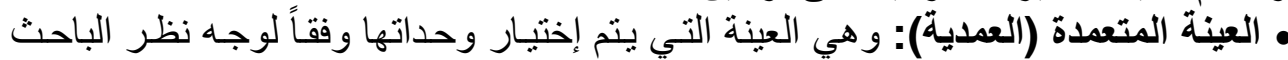
في اتقاده أنها تعطي نتائج مرضئة العية.

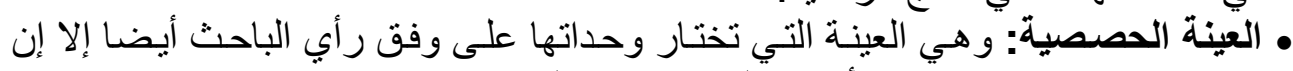
تركيبها يكون بحسب نسب الأجز اء الموجودة في المجتمع. 
ثثانياً تحديد حجم العينة

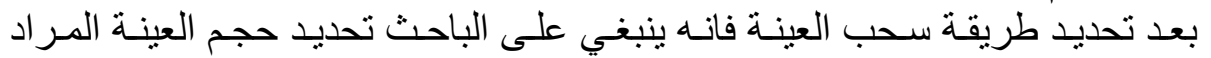

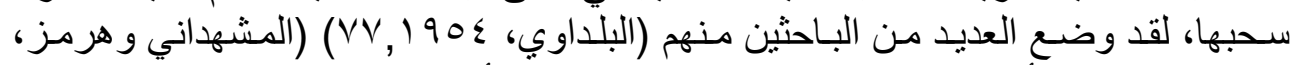

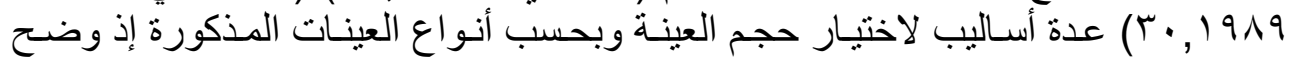

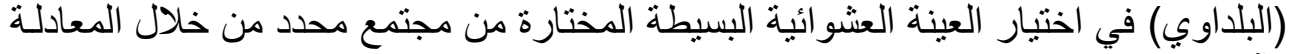

$$
\begin{gathered}
n=\left(\frac{Z S}{d}\right)^{2} \\
\mathrm{Z}=\mathrm{Z}(1-\alpha / 2)
\end{gathered}
$$

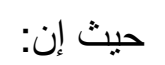

و التي يتم استخدامها من جداول التوزيع الطبيعي القياسي Z وان

$$
d=|\bar{x}-\mu|
$$

حيث إن: و و تمثل الوسط الحسابي للمجتمع. وإن S تمثل الانحر اف المعياري للمجتمع.

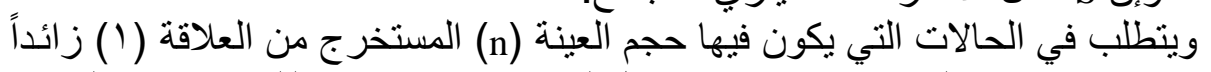
عن (• (\%) من حجم المجتمع N إجراء تعديل لغرض تخفيضها وذلك باستخدام العلاقة الآتية:

$$
n=\frac{n}{1+\frac{n}{N}}
$$

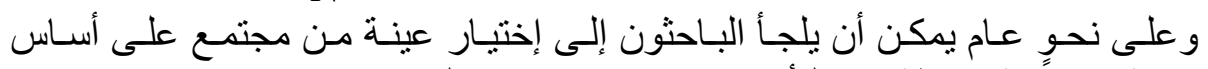

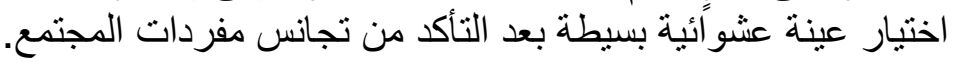

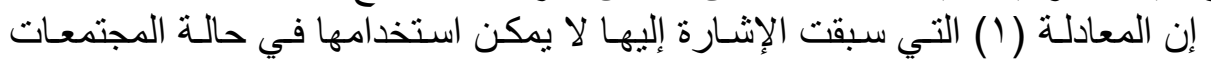

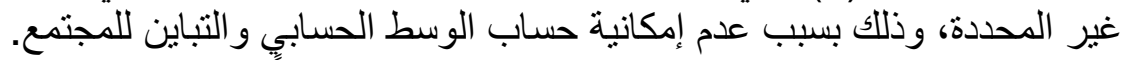

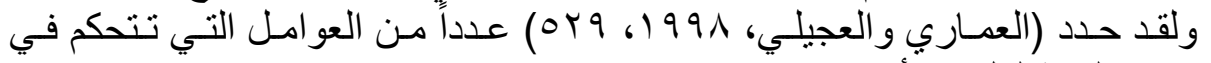

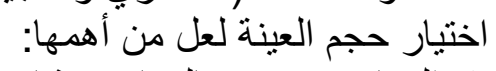

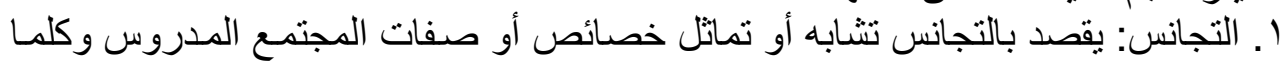

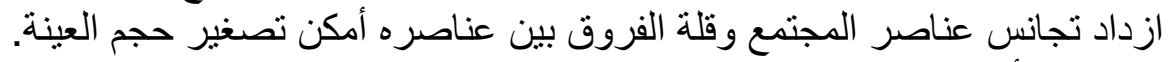

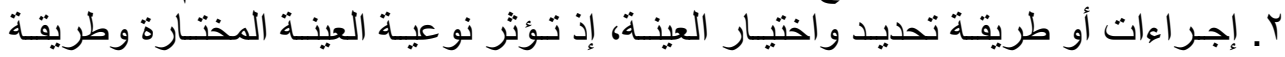

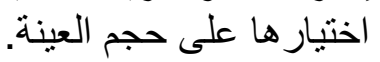
r. الوقت والموارد البشرية المتاحة للارداسة لهار دور كبير في تحديد حجم العينة، أو كلما

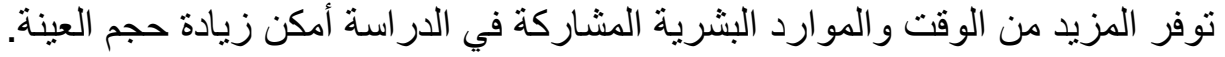

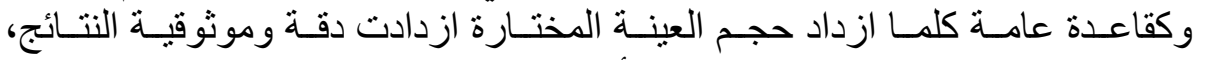
و اتسعت إمكانية تعميم نتائجها على المجتمع المأخوذة منه. 


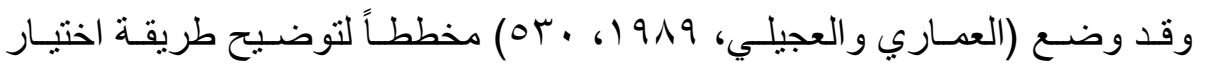

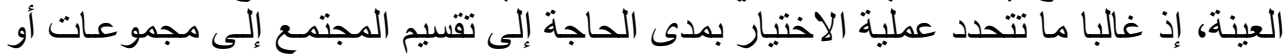
طبقات، وبمدى تو افر العينات وكما هو موضح بالثنكل الآني:

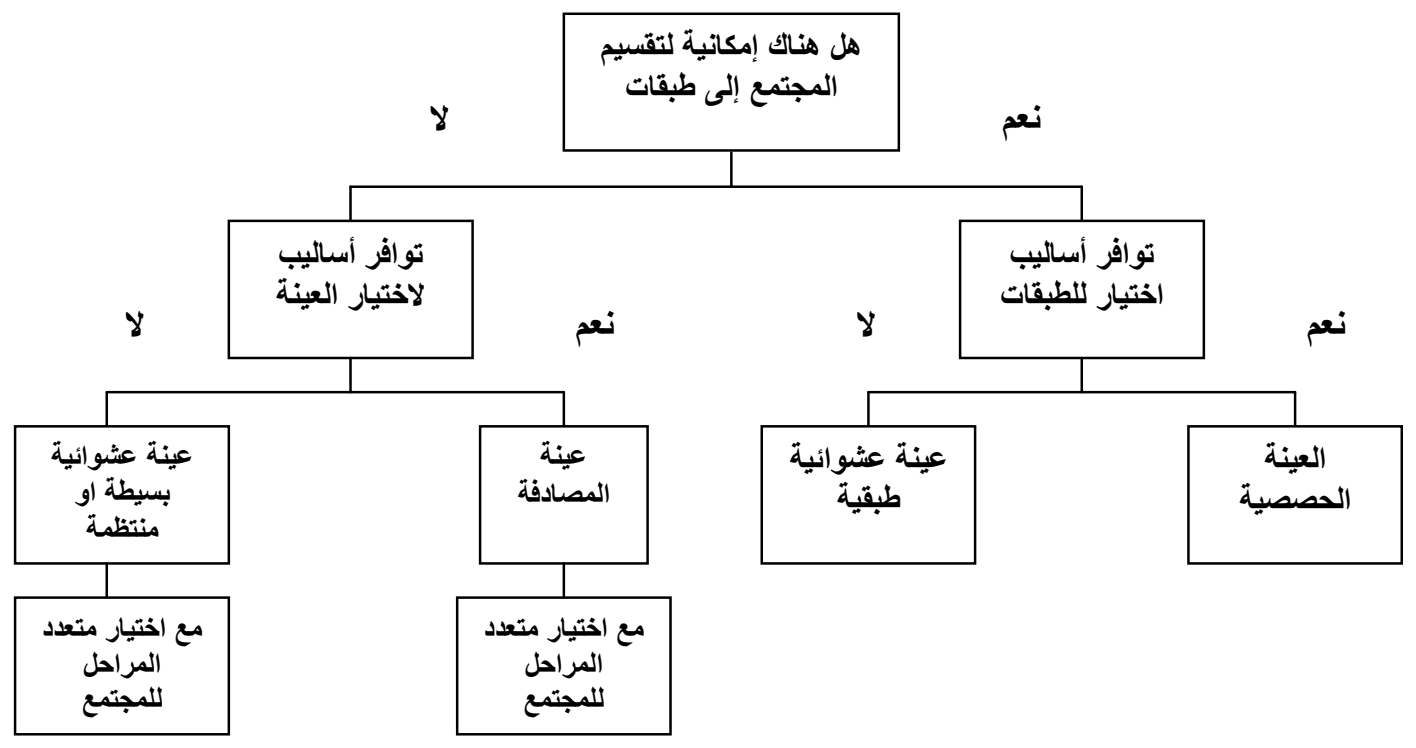

\section{1 مخطط \\ طريقة اختيار العينة}

المصدر: العمـاري، علي عبد السلام و العجيلي، علي حسين، (991))، أساسيات الإحصاء الرياضي،

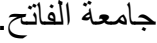

ثنالثاً ثبات أداة القياس

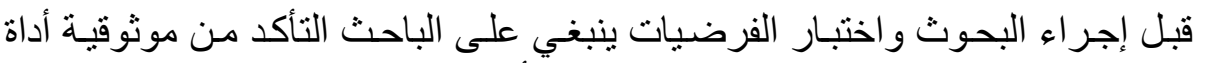

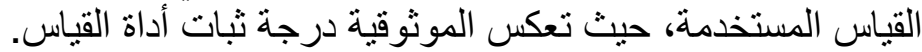

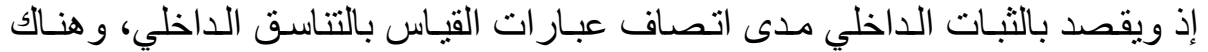

عدة مقاييس لاختبار الثبات الداخلي للأداة من أهمها معامل إلفا (Cronbach's alpha).

\section{طريقة (حتساب معامل ألفا}

يستخدم معامل الثبات (Cronbach's alpha) لقياس مدى ثبات أداة القياس من ناحية

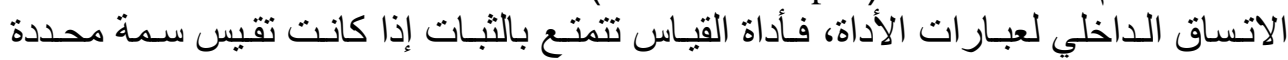

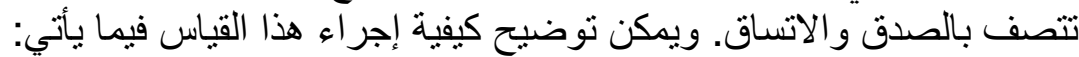

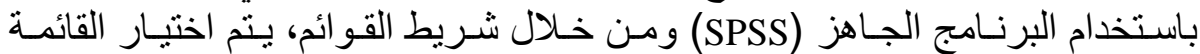

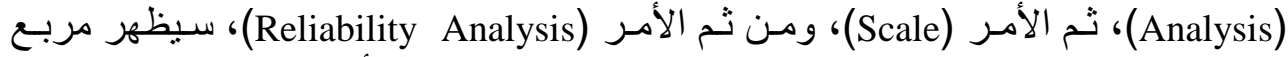

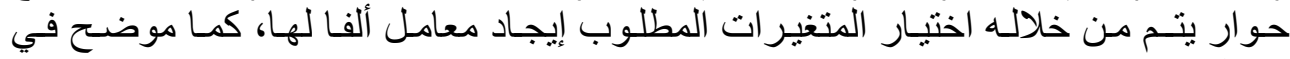




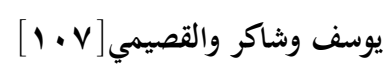

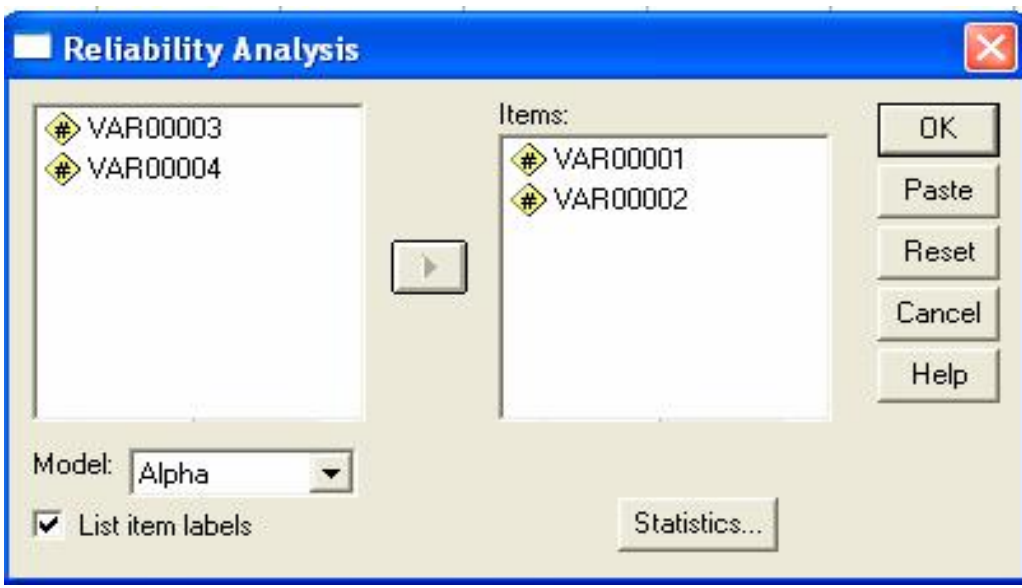

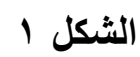

صندوق حوار معامل ألفا برنامج SPSS

في الجزءء الأيسر أسـل صـندوق الحـوار يـتم إختيـار الإيعـاز (Alpha) مـن الحقل (Model)

في حالة ظهور متغيرات غير منسقة مع بقية المتغير ات، قد يؤدي ذللك إلى تقليل قيمة

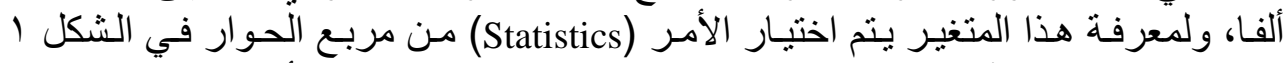

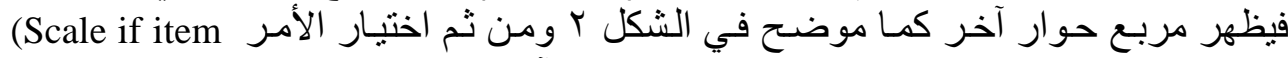

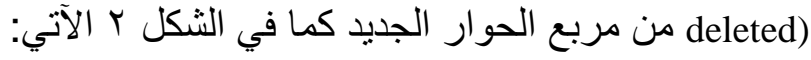




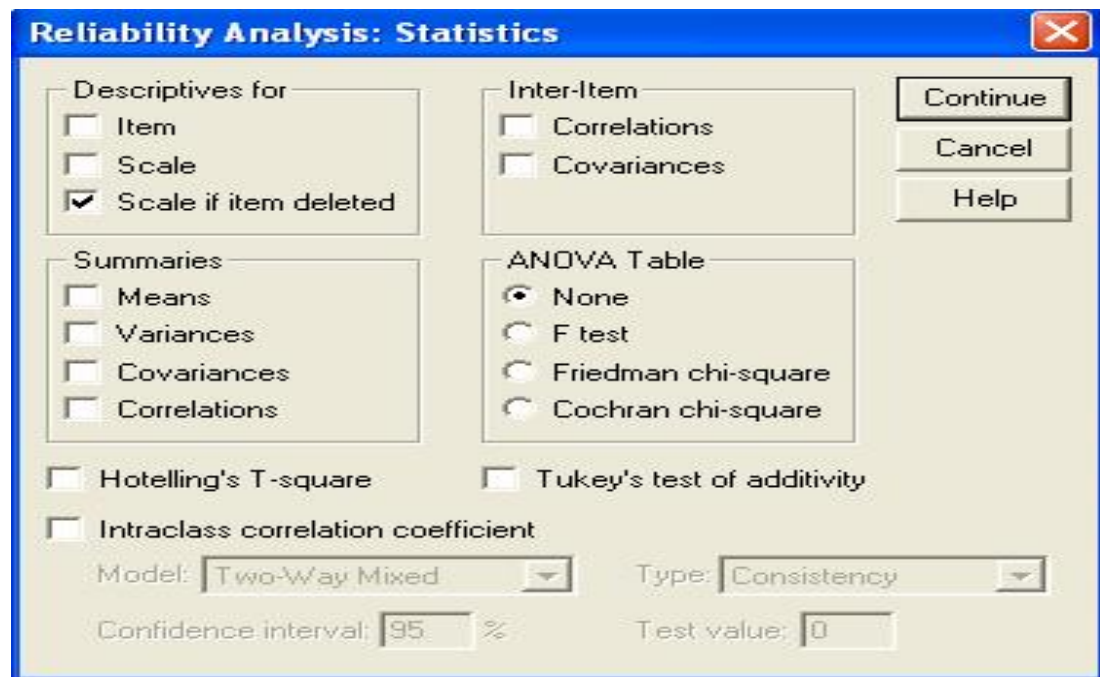

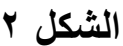

طريقة زيادة قيمة ألفا عتد حذف متغير معين

بعد ذللك يتم النقر على الأمر (continue) للعودة إلى المربع في الشكل )، (محفوظ،

رابعاً عودة البيانات لمجتمع يعود إلى التوزيع الطبيعي

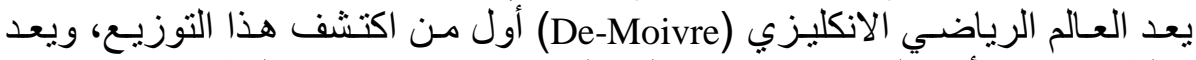

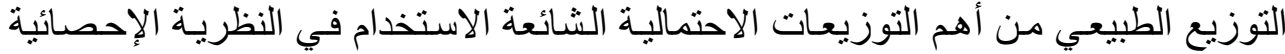

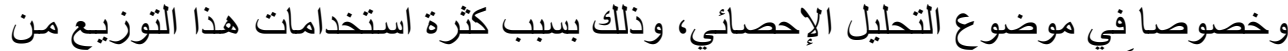

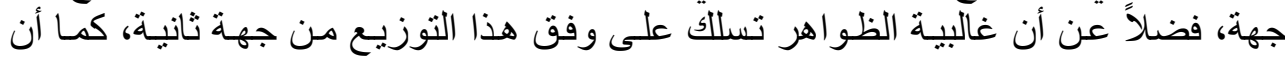

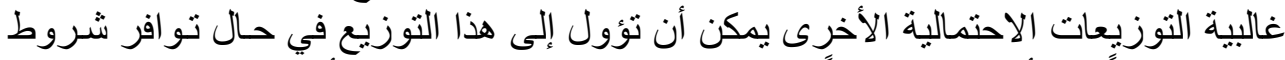

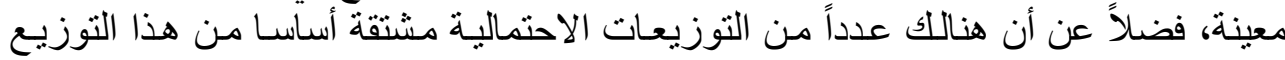

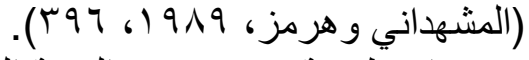

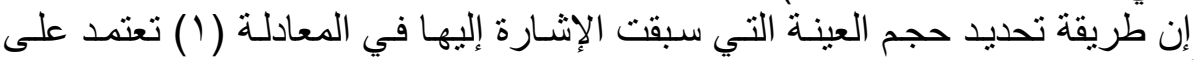

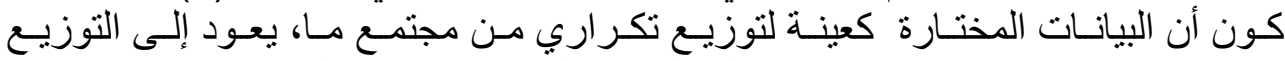

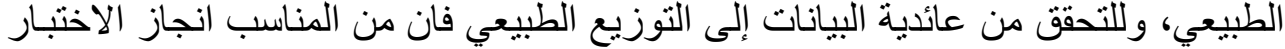

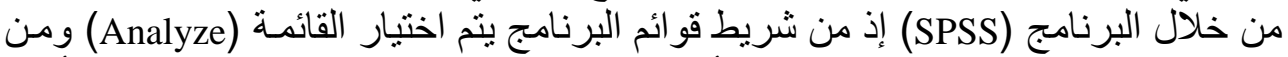

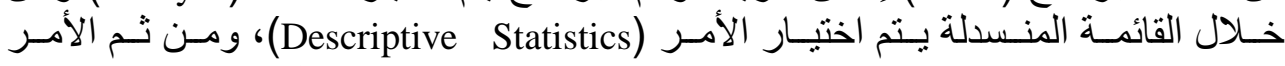

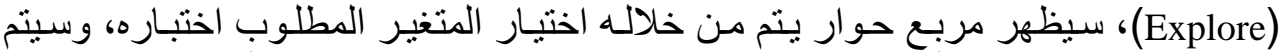

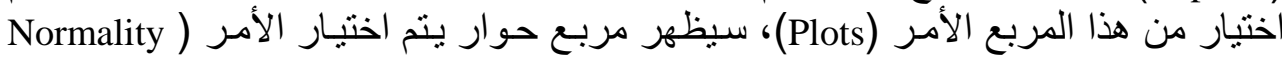
(Tests) (Plots With 
يوسف وشاكر والقصيمي[9]

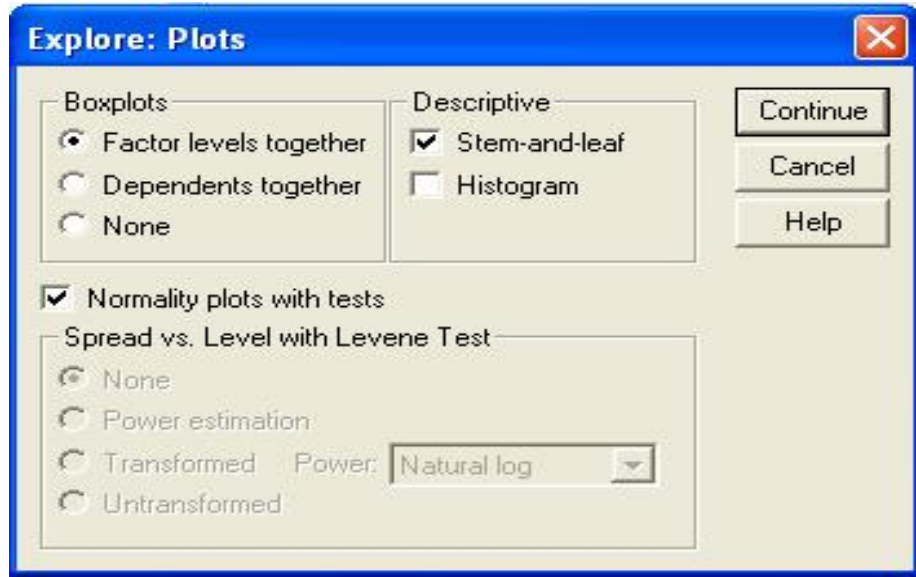

\section{الثكل r}

اختبار عودة البيانات إلى مجتمع يعود إلى التوزيع الطبيعي في برنامج (SPSS)

كمـا يمكن إظهار رسم لمدرج تكراري للبيانـات مـع رسم منحنسى التوزيع الطبيعي

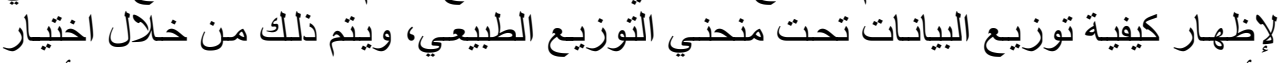

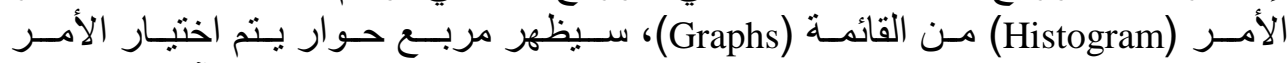
(Display Normal Curve)

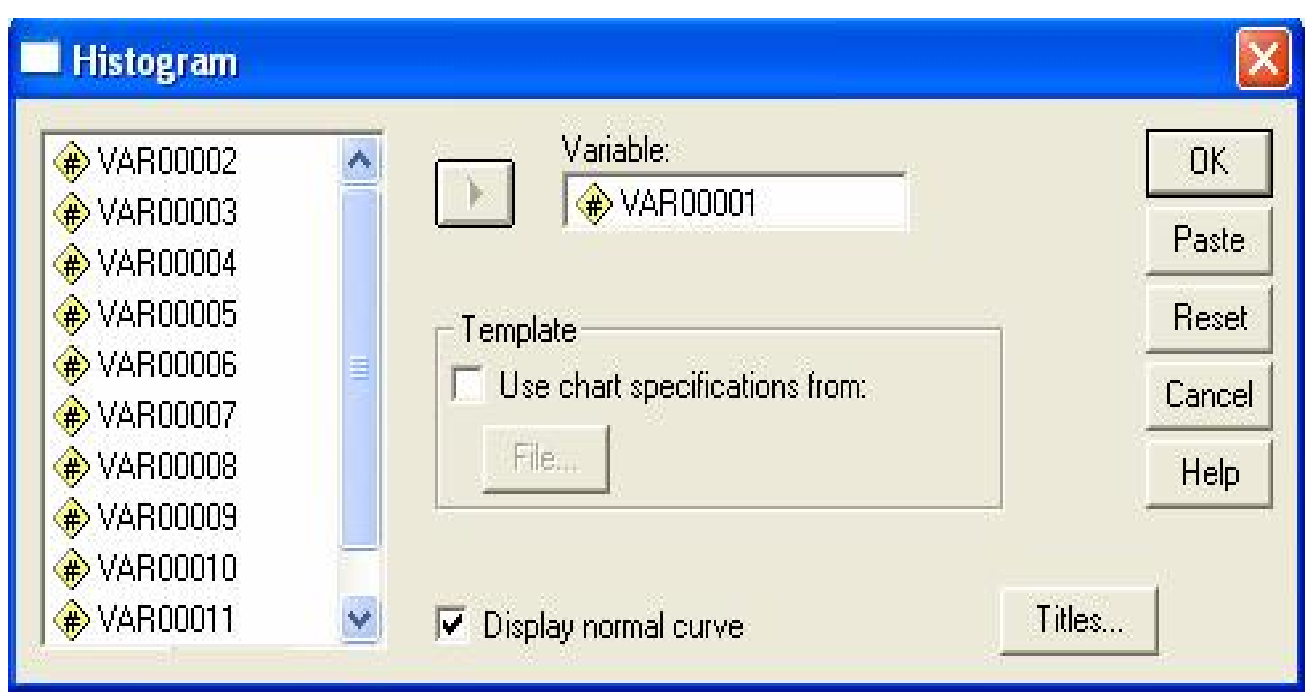

\section{الثكل ؛}

واجهة المدرج التكراري و منحنى التوزيع الطبيعي في برنامج (SPSS) 
يقصد بمعامل الارتباط قيمة توضح قوة وطبيعة العلاقة بين متغيرين سواء كانت هذه

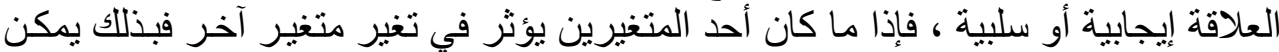

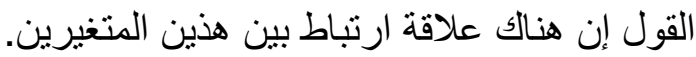

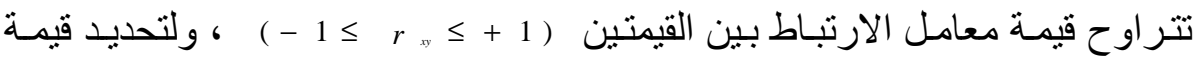

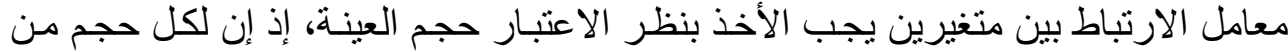

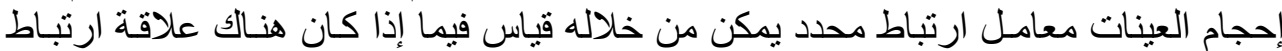

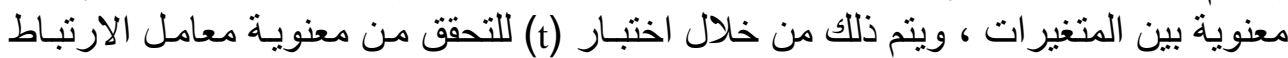

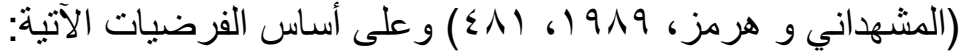

$H_{0}: \rho=0$

$H_{1}: \rho>0$

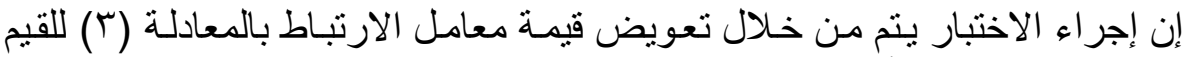

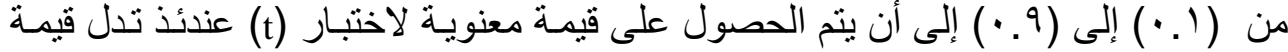

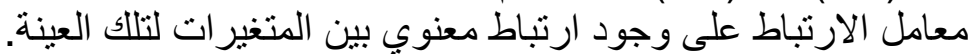

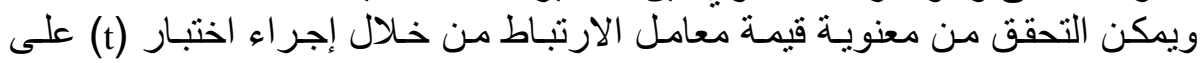

$t_{C A L}=r \sqrt{\frac{n-2}{1-r^{2}}}$

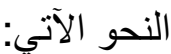

حيث إن: (t) (t) الجدولية المستخرجة من الجداول الإحصائية. في حين إن الرمز (r) يمثل قيمة معامل الارتباط الذي سيتم التعويض عن التها.

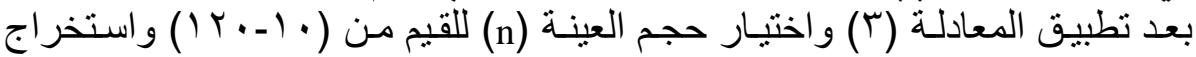

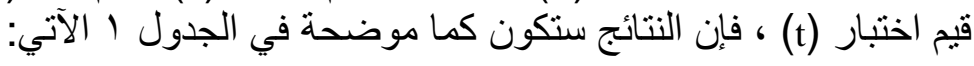

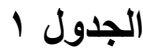

قيم معامل الارتباط لاختبار (t)

\begin{tabular}{|c|c|}
\hline قيمة معامل الارتباط & حجم العينة \\
\hline .7 & $10-1$. \\
\hline .0 & $r \varepsilon-17$ \\
\hline$\cdot . \varepsilon$ & $\leqslant r-r_{0}$ \\
\hline 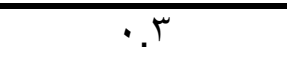 & $q r-\varepsilon r$ \\
\hline$\because Y$ & $T r \cdot-9 r$ \\
\hline .1 & ا Y| فما فوق \\
\hline
\end{tabular}

الجدول من إعداد الباحثين

يوضـح الجدول ا القيمـة المعنويـة لمعامـل الارتبـاط بـين المتغيـرات لكل حجم عينـة أنسواع معــاملات الارتبـاط: تقـسم معـاملات الارتبـاط علـى نــوعين (المسشهداني مختارة.

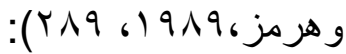




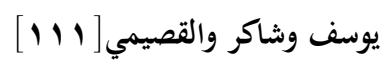

أ. معامـل الارتبـاط لكـارل بيرسن: يستخدم هذا المعامـل لإيجـاد الارتبـاط بين المتغيرات

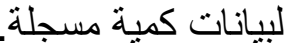
ب. معامل الارتبـاط لسبيرمان: يختص هذا المعامل بإيجاد الارتباط بين المتغيرات التئي التئي

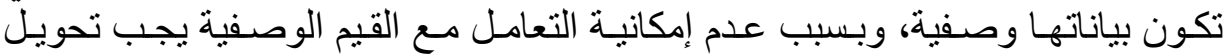

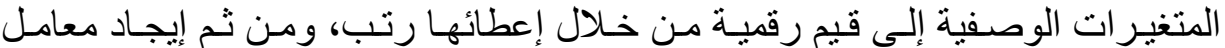

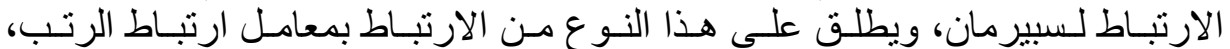

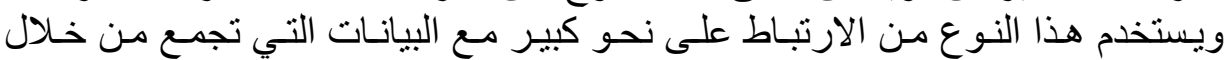

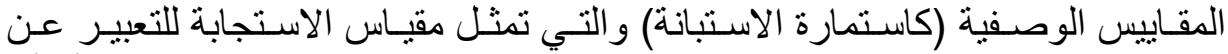

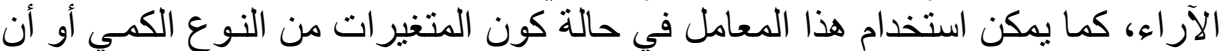

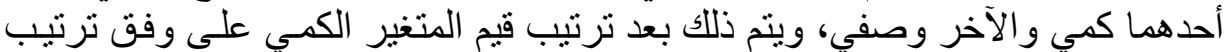

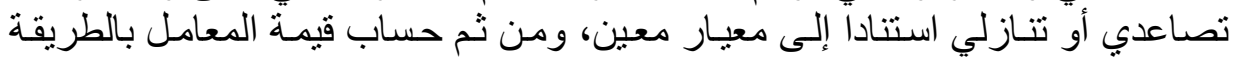

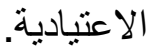

المحور الثاني- استخدام البرمجيات الإحصائية الجاهزة

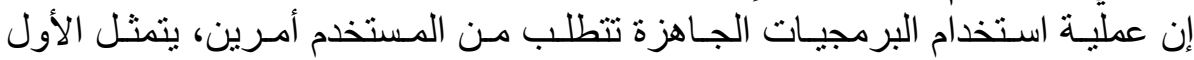

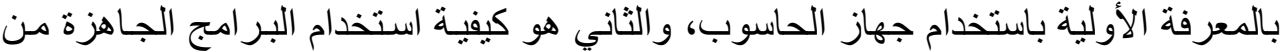

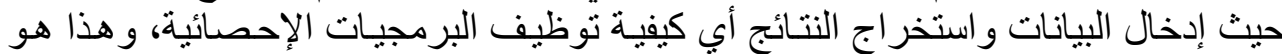

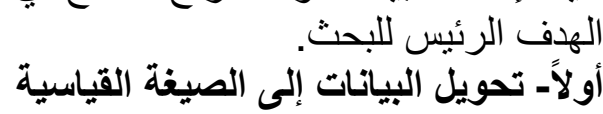

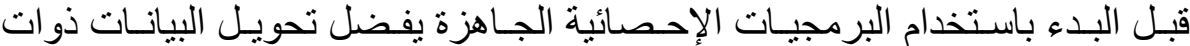

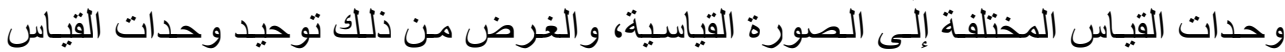

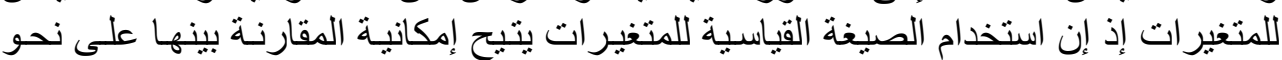
واضح، لذا فإن اللجوء إلى تحويل البيانات إلى القيم القياسية يعد أكثر فاعلية في عملية

وتوجد صيغتان لتحويل المتغيرات إلى الصورة القياسية (الراوي، 919 1، ـ 11).

ا ـ صيغة الانحراف الطبيعي: يقصد بهذه الصيغة تحويل قيم المتغيرات إلى الصيغة العائدة $Z_{i j}=\frac{X_{i j}-\bar{X}}{S_{j}}$ للتوزيع الطبيعي القباسي (Z) وكما يأتي:

$S_{j}{ }^{2}=\frac{\sum\left(X_{i j}-\bar{X}^{2}\right.}{(n-1)}$

r. . صيغة الثابت بطول واحد: يطلق على هذه الصيغة مصطلح "طول و احد"، وذلك لأن

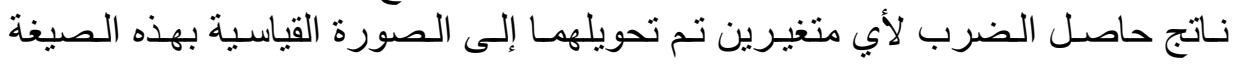

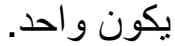
و الصيغة الرياضية لهذا التحويل تأخذ الثكل الآتي: 
$Z_{i j}=\frac{X_{i j}-\bar{X}}{d_{j}}$

$d_{j}{ }^{2}=\sum\left(X_{i}-\bar{X}\right)^{2}$

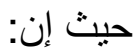

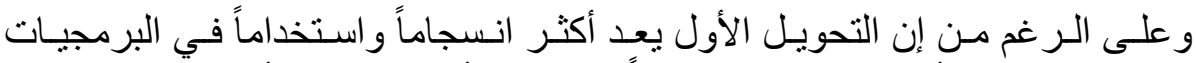

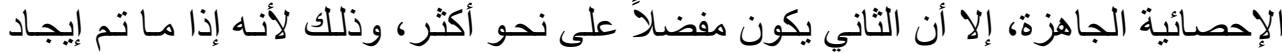

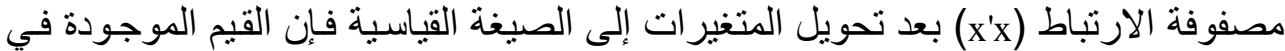

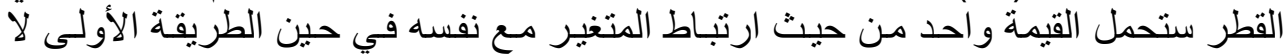

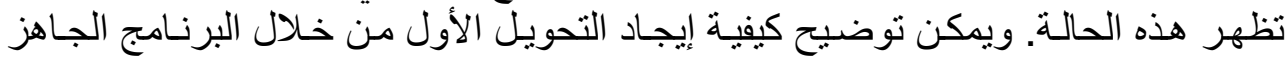

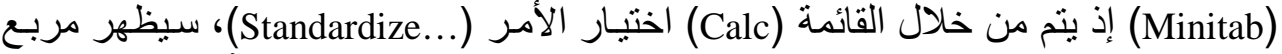
حوار يتم من خلاله اختيار المتغير ات المطلوبة كما موضح في الثكل ه الآتي:

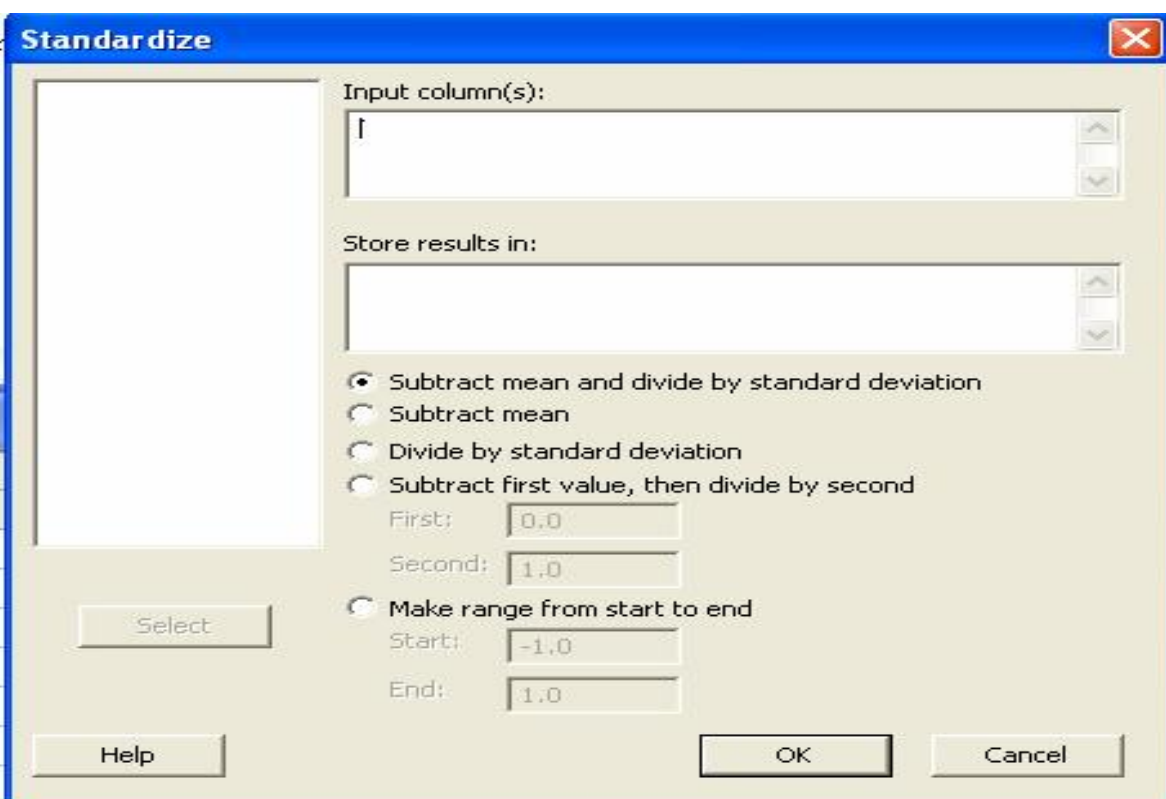

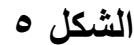

تحويل المتغير إلى الصيغة القياسية في برنامج (Minitab)

ثاتياً- تحليل البيانات

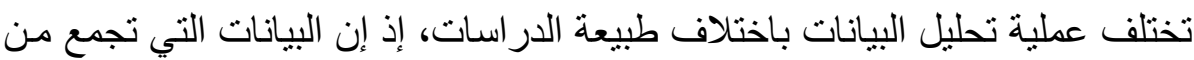

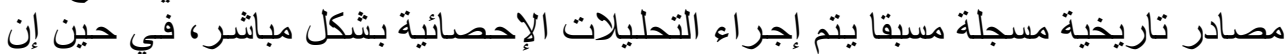


يوسف وشاكر والقصيمي[1

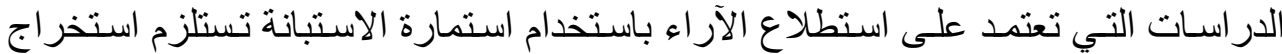
الإحصاءات الوصفية و التكر ارات و النسب المئوية قبل البداء بالئ بالتحليلات الإحصائية.

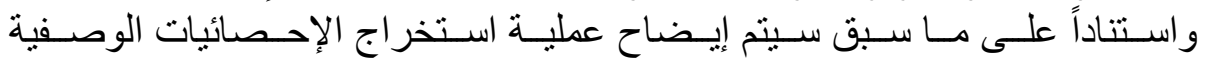

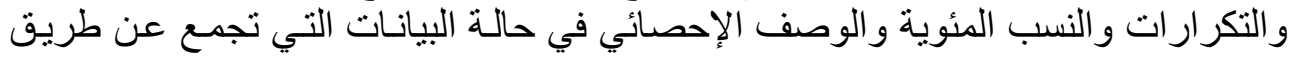

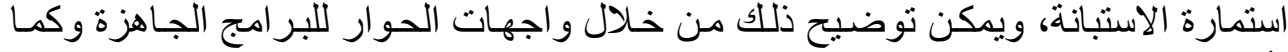

$$
\text { ا أستخراج التكرارات والنسب المئوية }
$$

يقصد بالتكر ارات إيجاد عدد مرات طئ ظهور قيمة محددة من قيم المشاهدات في المتغير

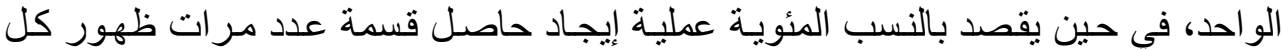

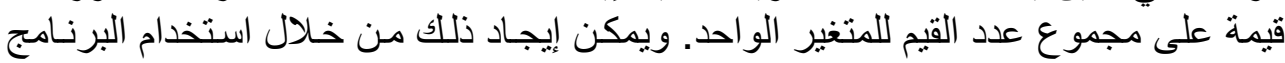

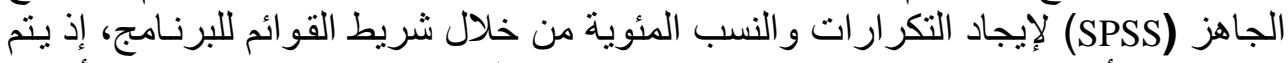

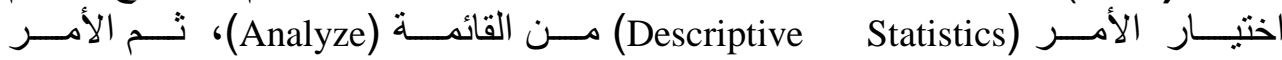
سيظهر مربـع حوار، سيتم مـن خلالـه اختيـار المتغير المطلوب إيجـاد (Frequencies...) التكر ارات و النسب المئوية كما موضطح في الثكل 1 الآتي:

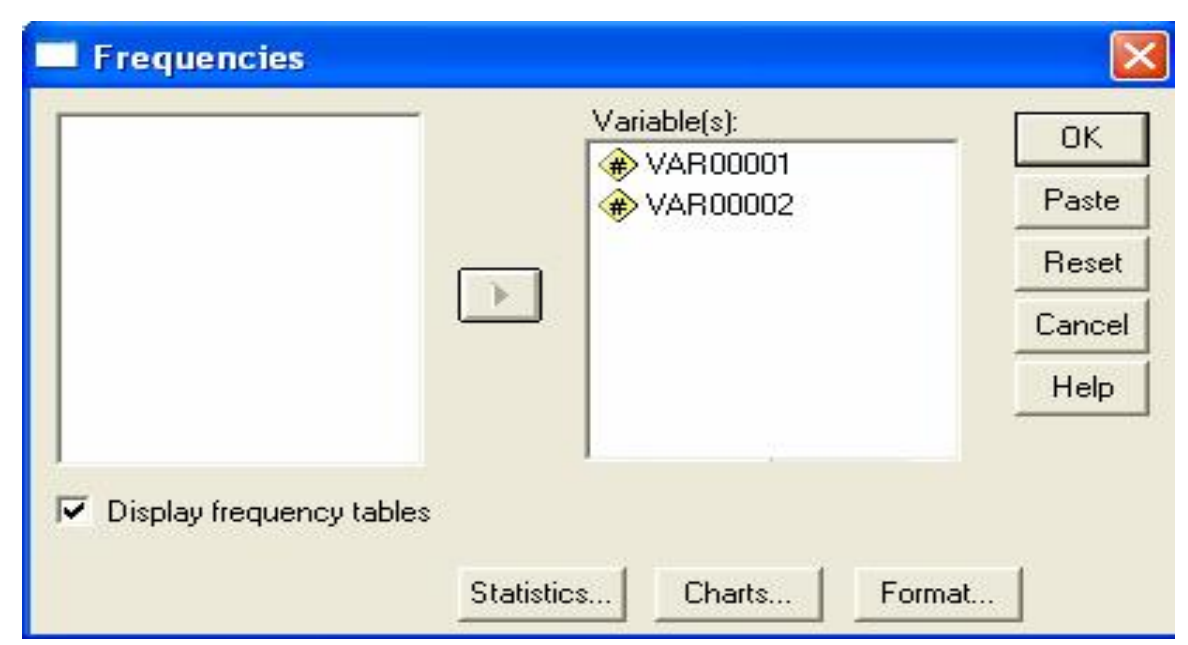

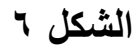

صندوق حوار اختيار المتغيرات المطلوبة لبرنامج (SPSS) لإيجاد التكرارات والنسب المئوية ليرنامج

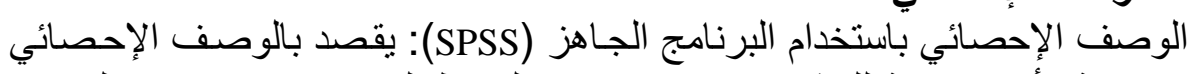

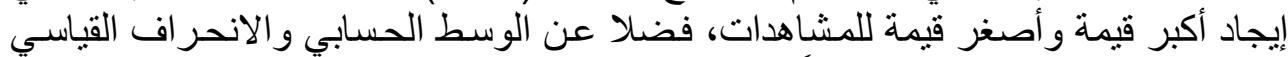

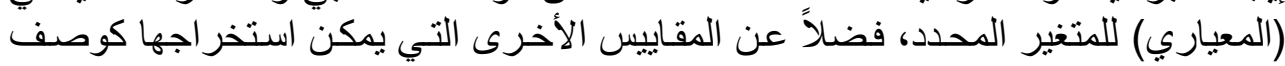

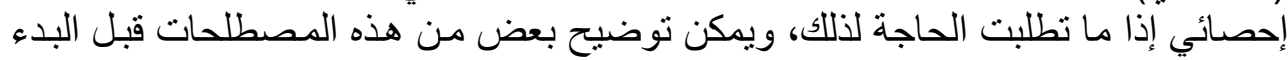

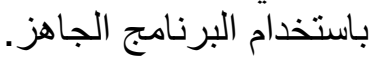
وتجدر الإشارة إلى أن قيمة الانحر اف القياسي كلمـا كانت صـغيرة كانت أفضل، إذ إذ

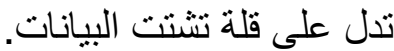




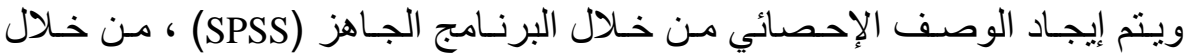

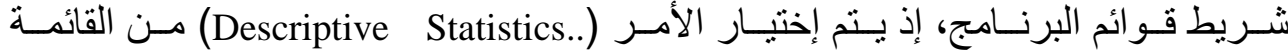

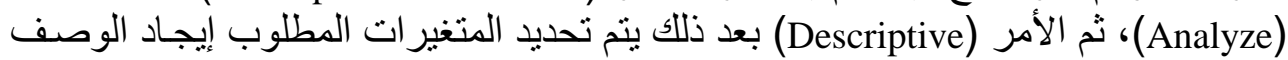
الإحصائي لها.

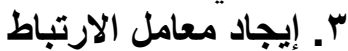

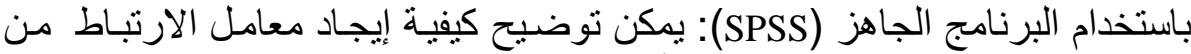

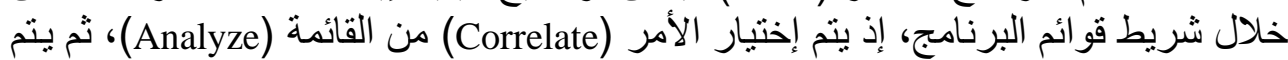

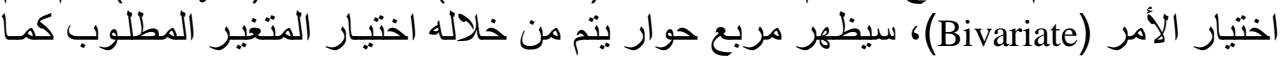
موضح في الثكل V الآتي:

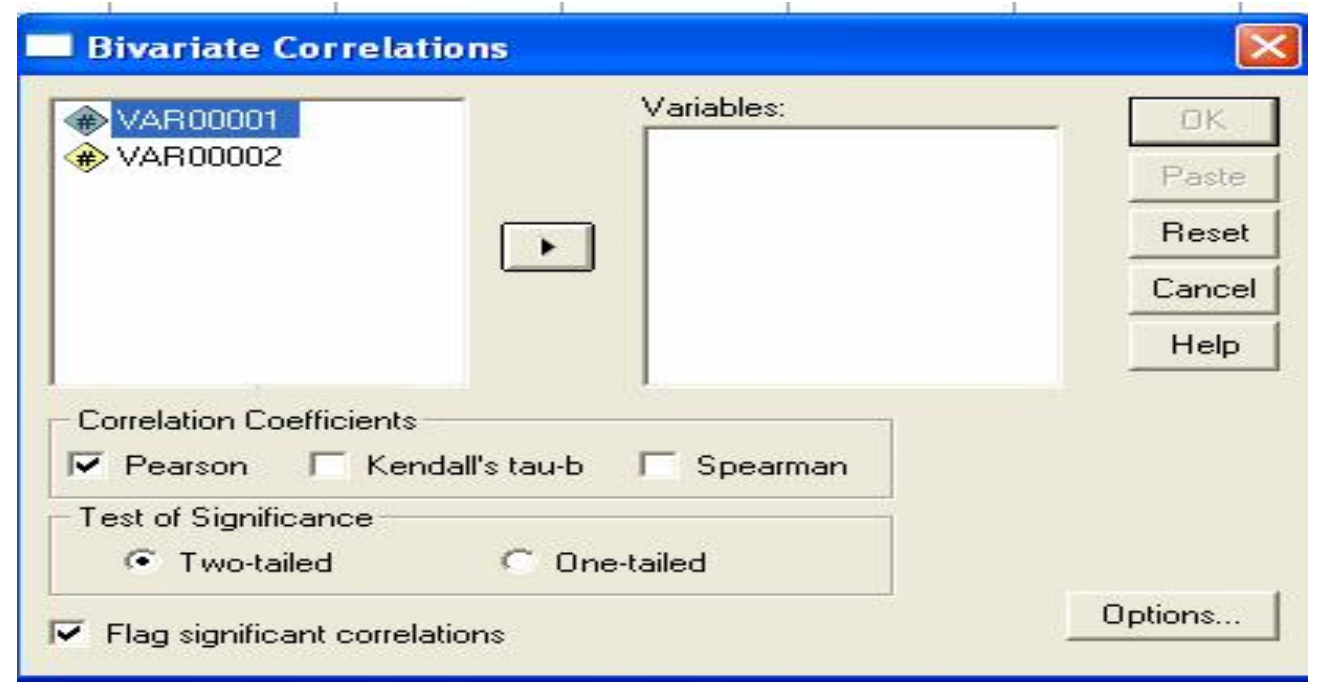

V الشكل

واجهة إيجاد معامل الارتباط اختيار في برنامج (SPSS)

من خلال صندوق الحوار أعلاه يمكن إيجاد معامل الارنباط لكل من كارل (بيرسن

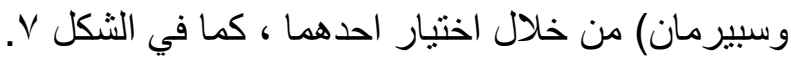

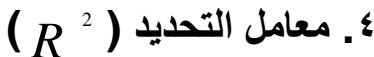

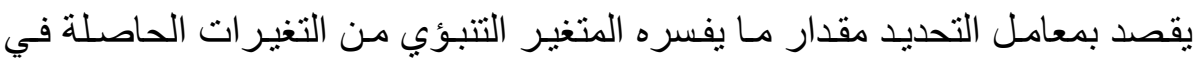

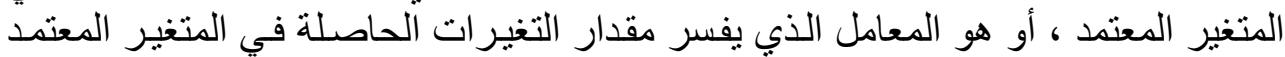

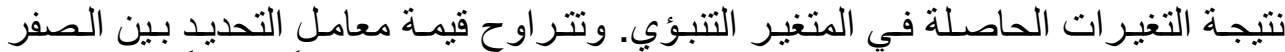

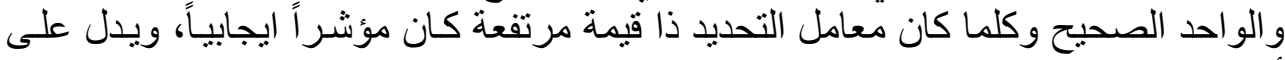

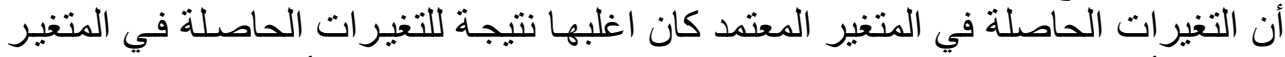

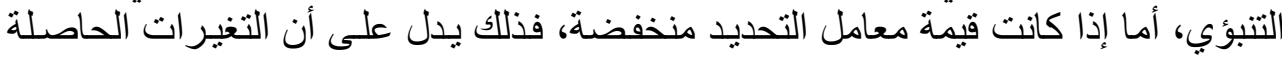

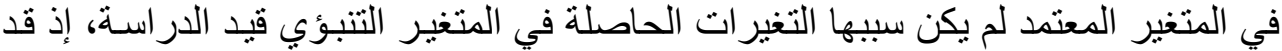

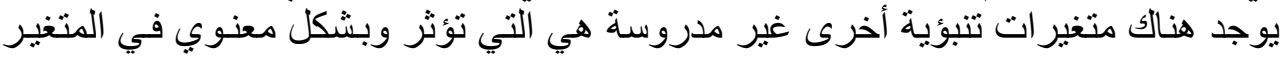

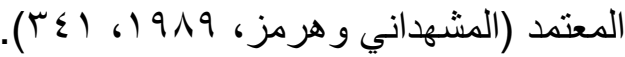


يوسف وشاكر والقصيمي[110]

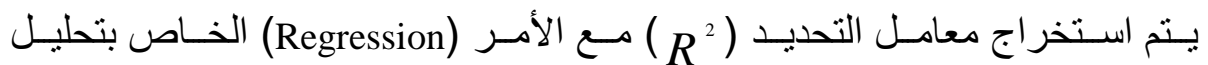

الانحدار.

ثالثاً. تحليل الاتحدار

يعرف الانحدار (أو تحليل الانحدار Regression Analysis) بشكل عام بأنها مقياس

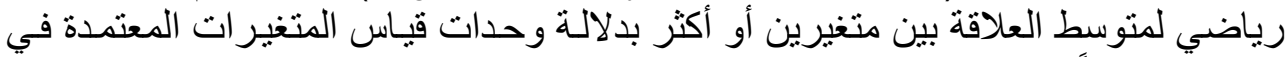

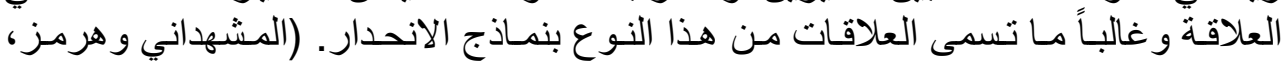

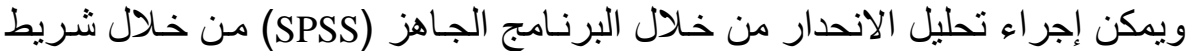

(Tr 19199

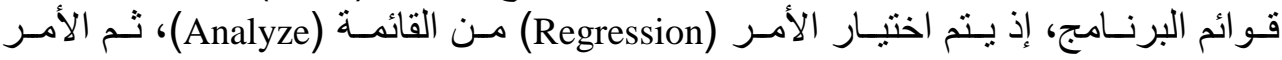

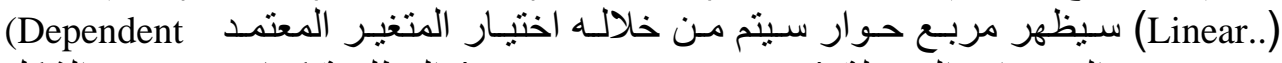

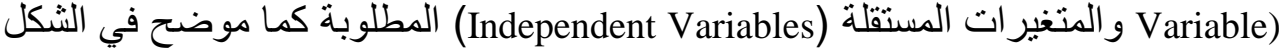
م الآتي.

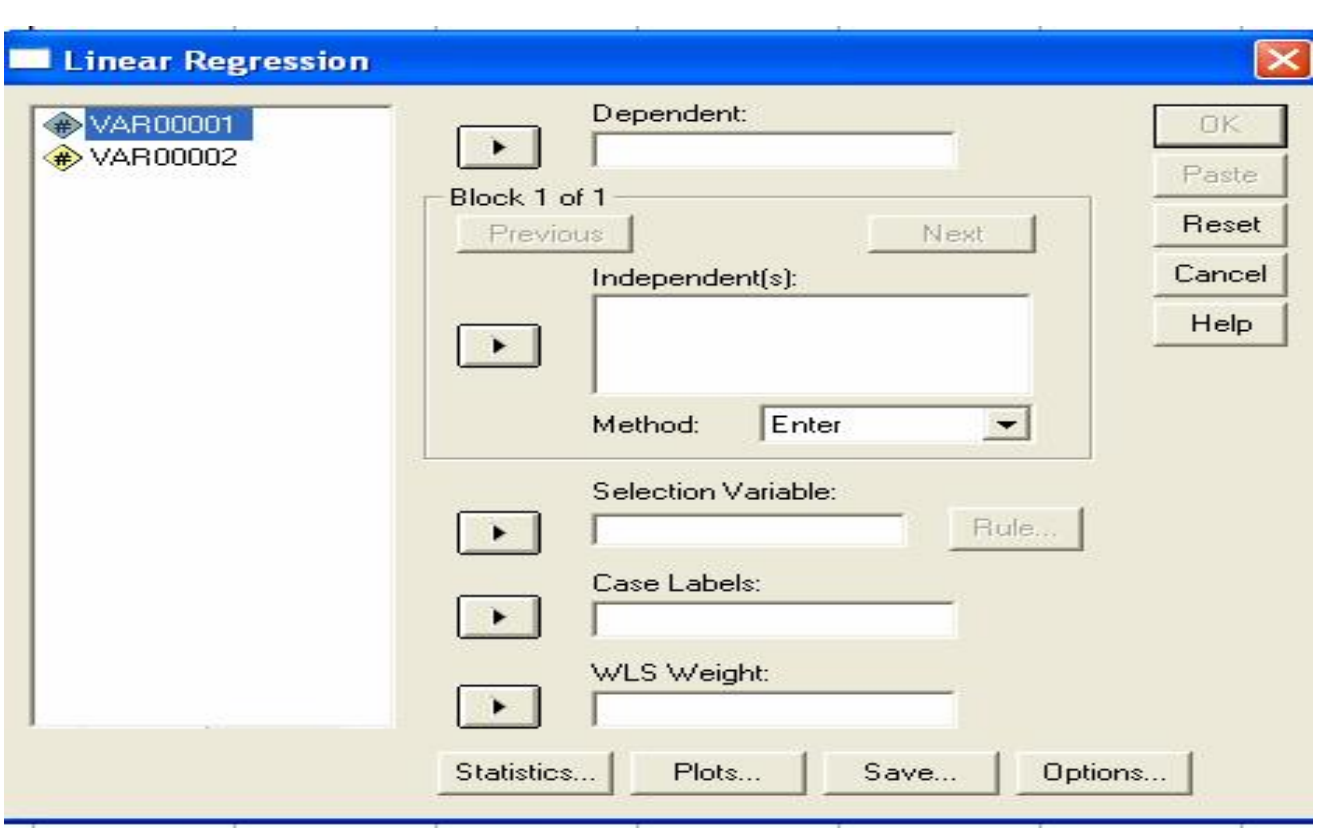

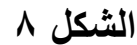

تحديد المتغيرات التنبوئة والمتغير المعتمد في برنامج (SPSS) لإيجاد معاملات

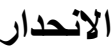

رابعاً- الثاجل الخطي بين المنعيرات

بعد التحقق من عودة البيانات إلى التوزيع الطبيعي و إجراء التهاء التحليلات الإحصائية

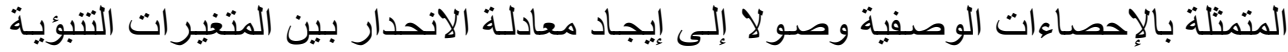

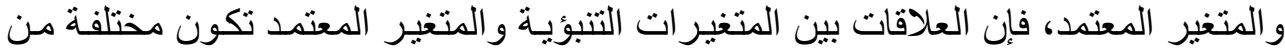

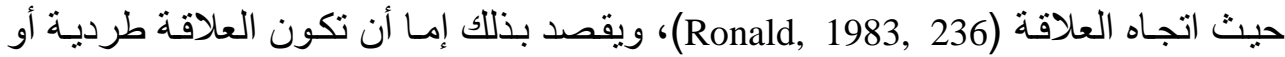
عكسية، فعلى سبيل المثال علاقة متغير أداء الأفراد تتناسب طرديا (إنشارة موجبة) مع نظام العام 


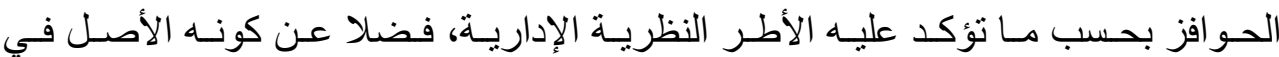

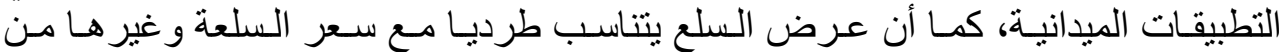

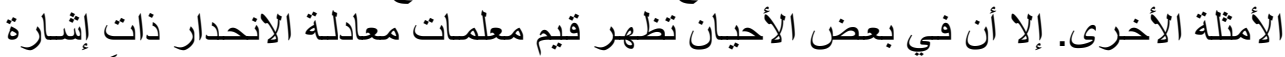

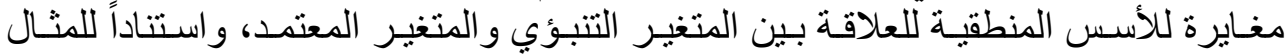

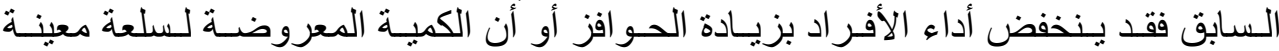
تنخفض بزيادة سعر تلك السلعة بسبب وجود متغيرات أخرى تؤثر على طبل طبيعة العلاقة.

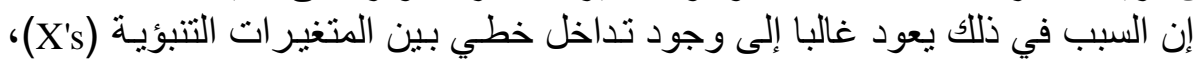
فعند التخلص من مشكلة التداخل الخطي بين المتغيرات التنبؤية تعود هذه العلاقة إلى الشكل المنطقي من خلال معادلة الانحدار.

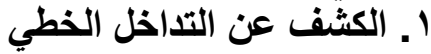

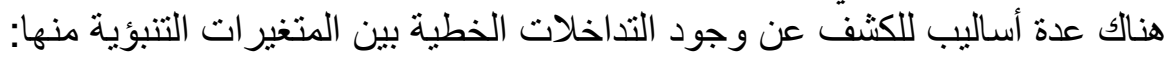

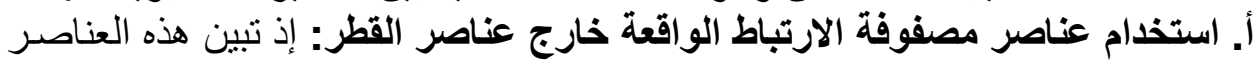

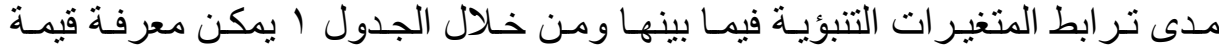

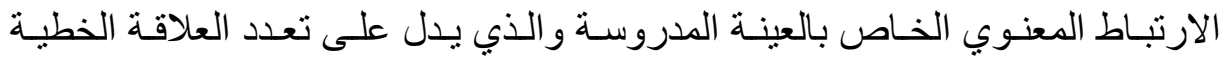
الموجودة بين المتغير ات التبوئية التباية. ب.عناصر القطر الرئيس للمصفوفة (Variance Inflation Factors)

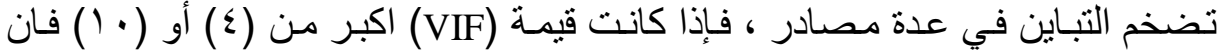

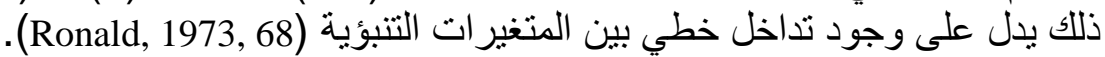

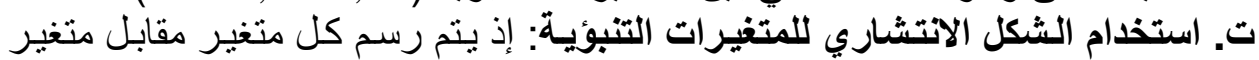

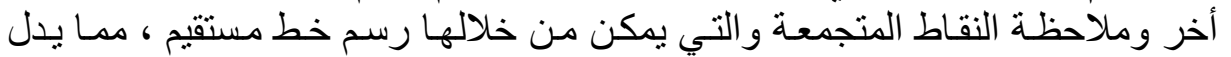

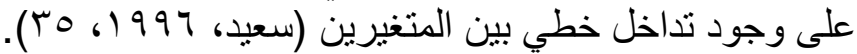

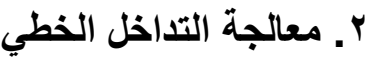

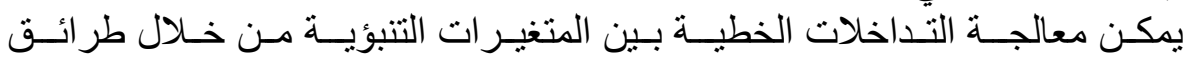

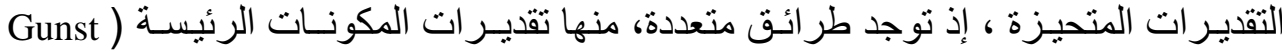

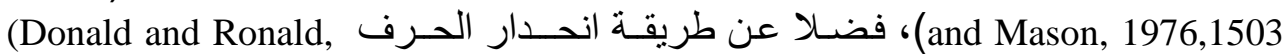

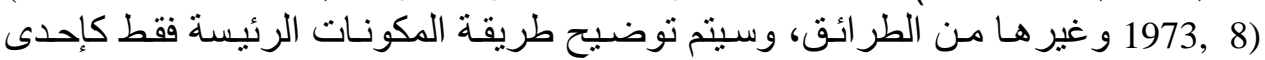
الطر ائق لمعالجة التداخلات الخطية بين المتغير ونير ات التنبؤية وكما يأتي:

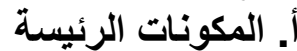

تعد طريقة المكونات الرئيسة إحدى الطر ائق المتحيزة المستخدمة في إعطاء تقديرات

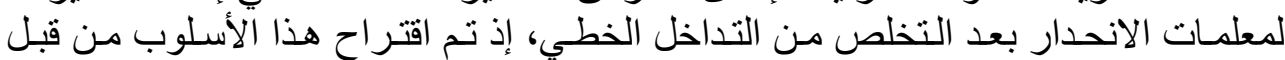

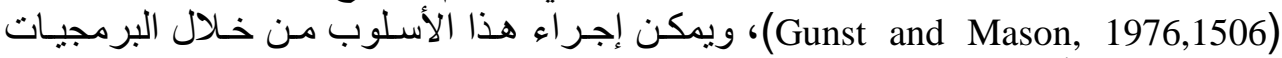

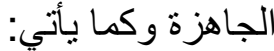

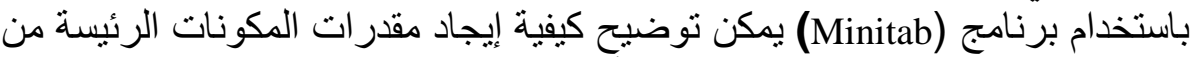

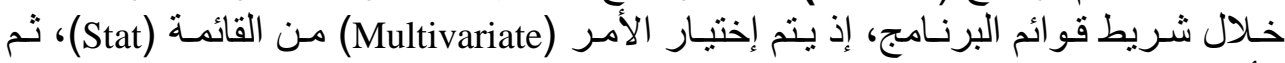

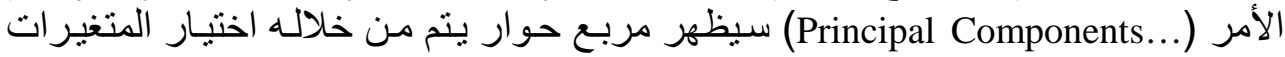
المطلوبة كما موضح في الثكل 9 الآتي: 


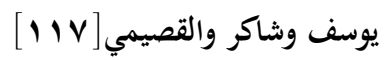

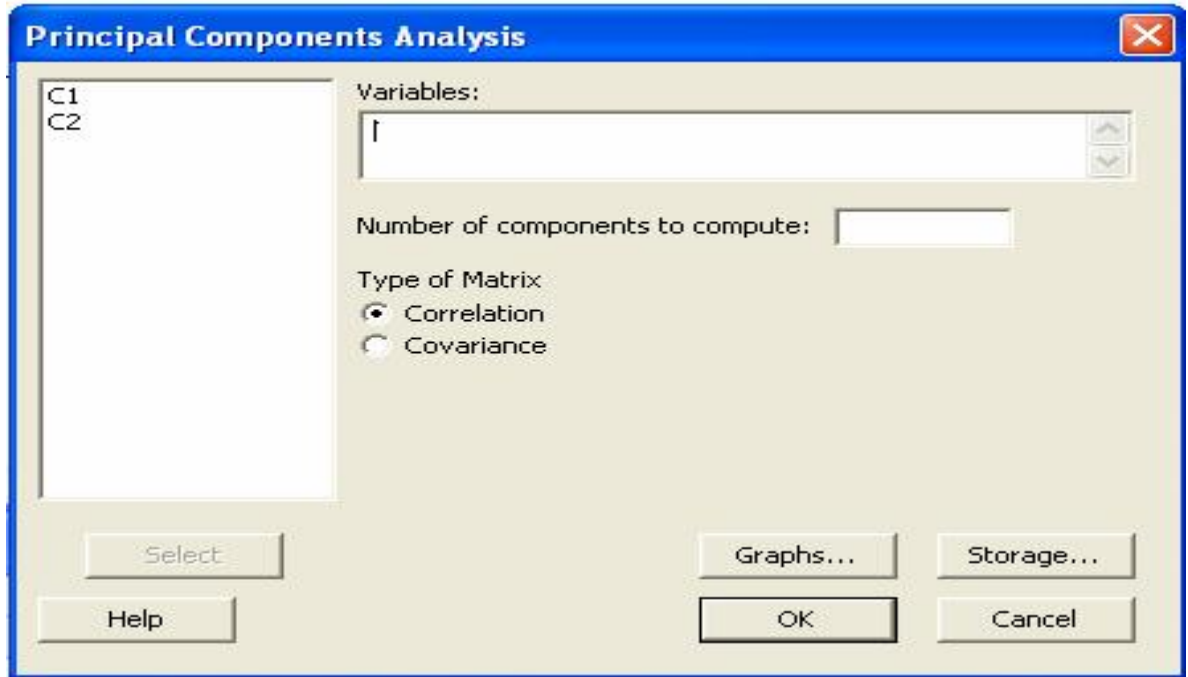

الثكل 9

واجهة الحوار لبرنامج (Minitab) المستخدمة في إيجاد المكونات الرئيسة

في هذا الجزء من البحث سيتم توضيح وتفسير النتائج من خلال منثال تجريبي لكي خامسـاً تفسير نتائج التحليل

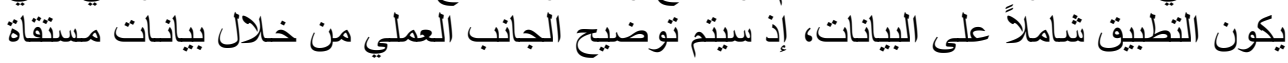

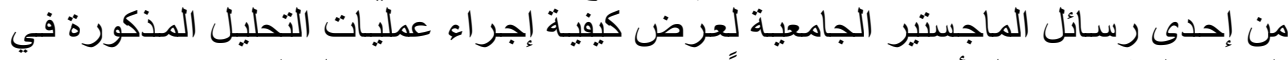

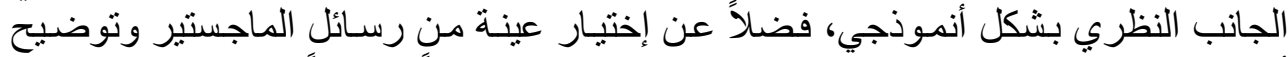

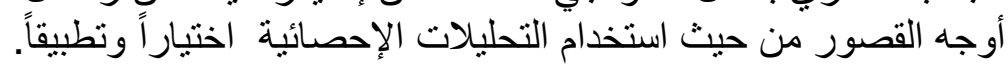

المحور الثالثـ- اختيار بيانات أنموذجية

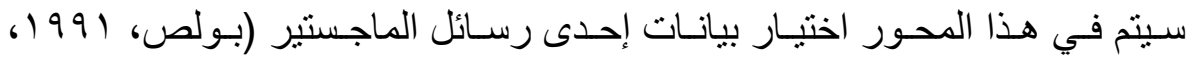

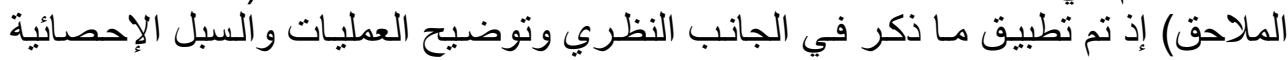

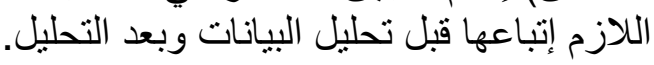

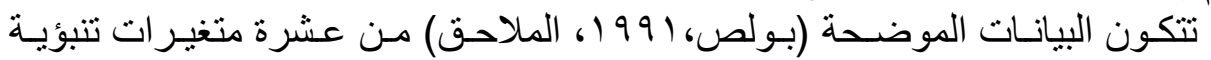

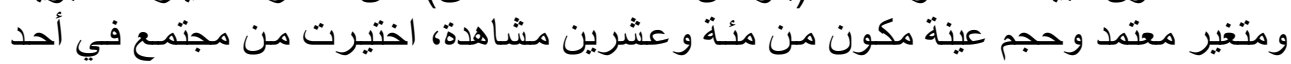

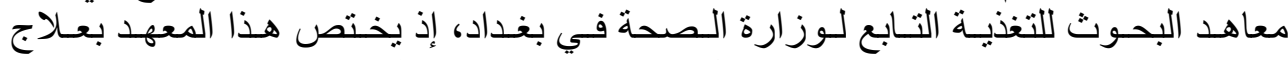

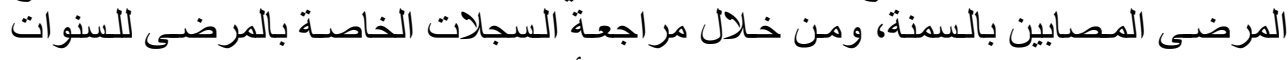

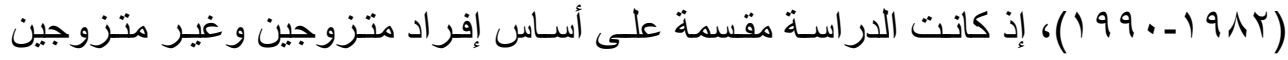

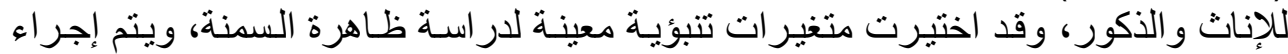

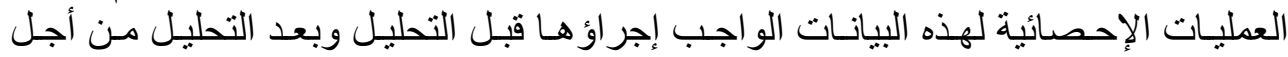

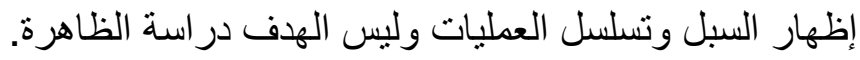
تتكون البيانات للمتزوجين من الإناث من المتغير الت آلات الاتية: المتغير المعتمد: Y= الوزن أما المتغير ات الاتن التنبؤية فهي:

= X3

= $X_{2}$

العمر 


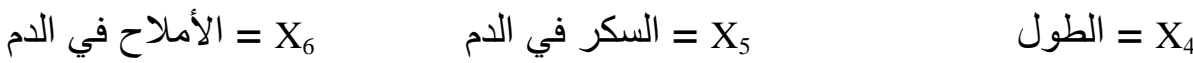

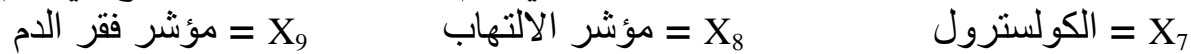

$$
\begin{aligned}
& \text { = X X }
\end{aligned}
$$

أولاً - تحديد أسلوب اختيار العينة

لقد تم اختيار البيانات من إحدى رسائل الماجستير لذا فقد تم إجراء هذه الخطوة على

$$
\text { نحو مسبق. }
$$

\section{ثناتياً ت تحيد حجم العينة}

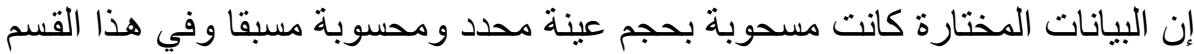

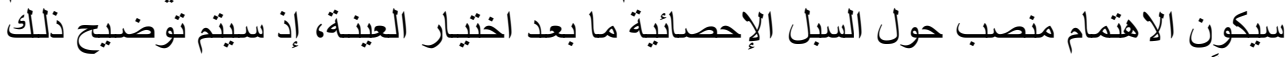
عملياً في الجانب التطبيقي من البحث بشكل مفصل.

ثالثاً إيجاد معامل ألفا

نظر اً لكون البيانات المستخدمة هي بيانات كمية وليست بيانات وصفية، لذا لا يستلزم الأمر إيجاد معامل ألفا (أداة الثبات).

\section{رابعاً عودة البيانات إلى مجتمع يعود إلى التوزيع الطبيعي}

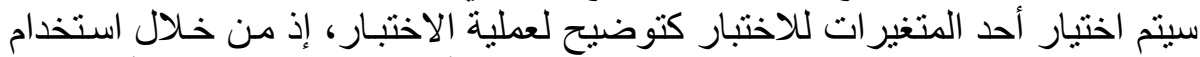

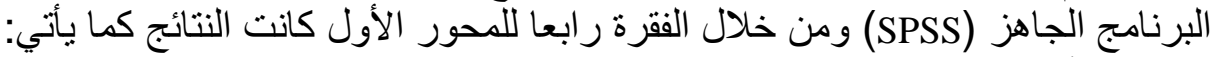

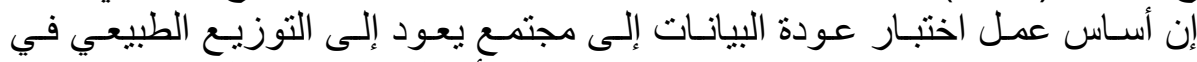

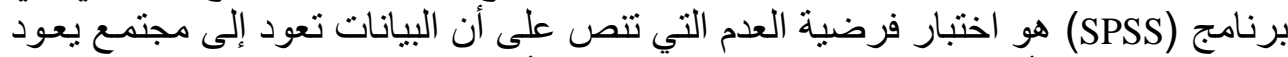

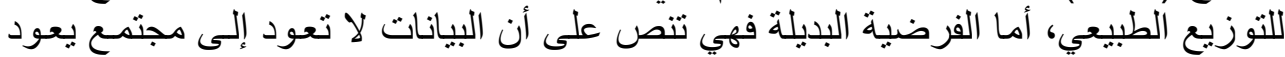
للتوزيع الطبيعي.

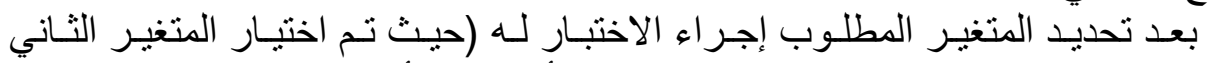

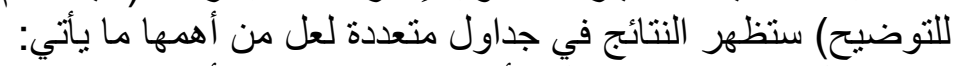

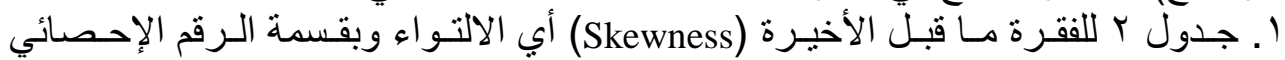
(Statistic)

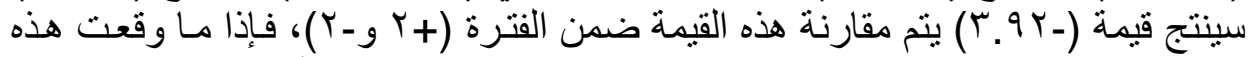

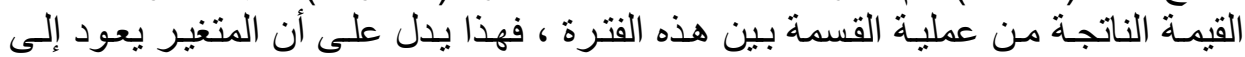

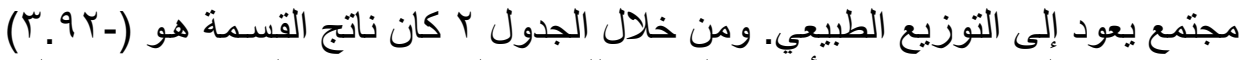

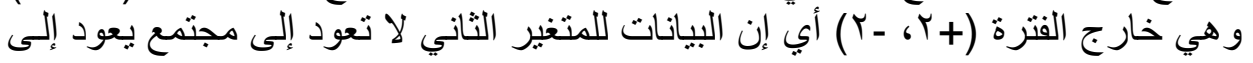
التوزيع الطبيعي.

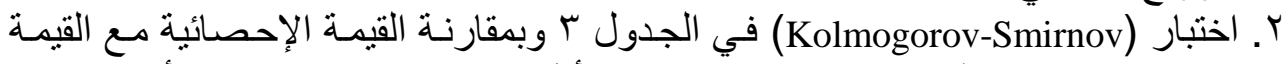

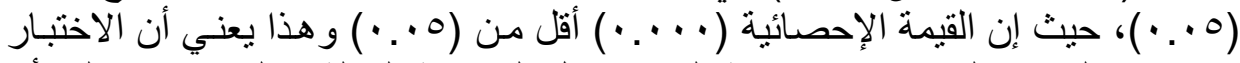

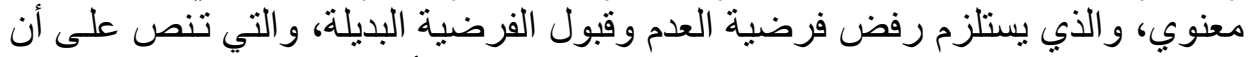

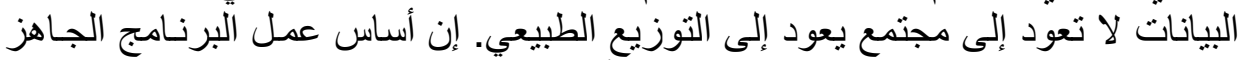
(SPSS)

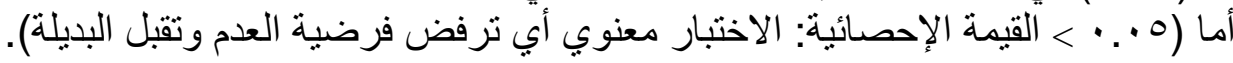


يوسف وشاكر والقصيمي[119]

أو (0 . . • > القيمـة الإحصائية: الاختبـار غير معنوي أي ترفض الفرضية البديلـة وتقبل فرضية العدم).

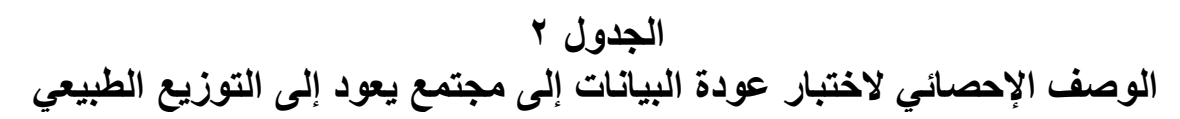

Descriptives

\begin{tabular}{|ll|r|r|}
\hline \multicolumn{2}{|c|}{} & Statistic & Std. Error \\
\hline Occupation & Mean & 5.3250 & .23792 \\
95\% Confidence & Lower Bound & 4.8539 & \\
Interval for Mean & Upper Bound & 5.7961 & \\
& & 5.4259 & \\
5\% Trimmed Mean & 7.0000 & \\
Median & 6.793 & \\
Variance & 2.60627 & \\
Std. Deviation & 1.00 & \\
Minimum & 8.00 & \\
Maximum & 7.00 & .221 \\
Range & 5.00 & .438 \\
Interquartile Range & -.868 & \\
Skewness & -1.155 & \\
Kurtosis & &
\end{tabular}

\section{الجدول r}

طريقة Kolmogorov-Smirnov لعودة البيانات لمجتمع يعود للتوزيع الطبيعي

Tests of Normality

\begin{tabular}{|l|r|c|c|c|c|c|}
\hline & \multicolumn{3}{|c|}{ Kolmogorov-Smirnov $^{\text {a }}$} & \multicolumn{3}{c|}{ Shapiro-Wilk } \\
\cline { 2 - 7 } & Statistic & $\mathrm{df}$ & Sig. & Statistic & df & Sig. \\
\hline Occupation & .415 & 120 & .000 & .658 & 120 & .000 \\
\hline
\end{tabular}

a. Lilliefors Significance Correction

r. يلاحظ من خلال الثكل · ( أن اقل من (•9\%) من النقاط تقع على جانبي خط الميل

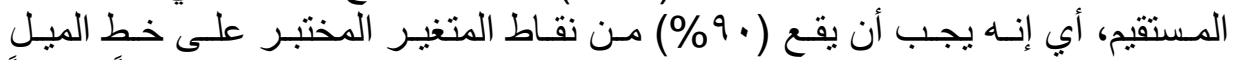

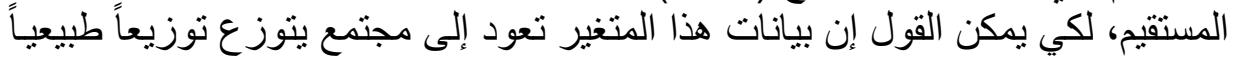

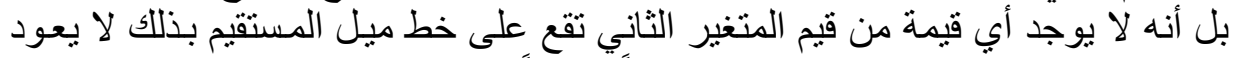

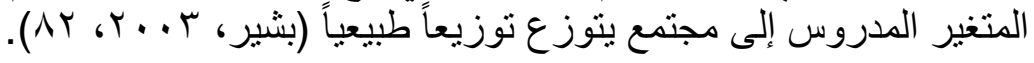




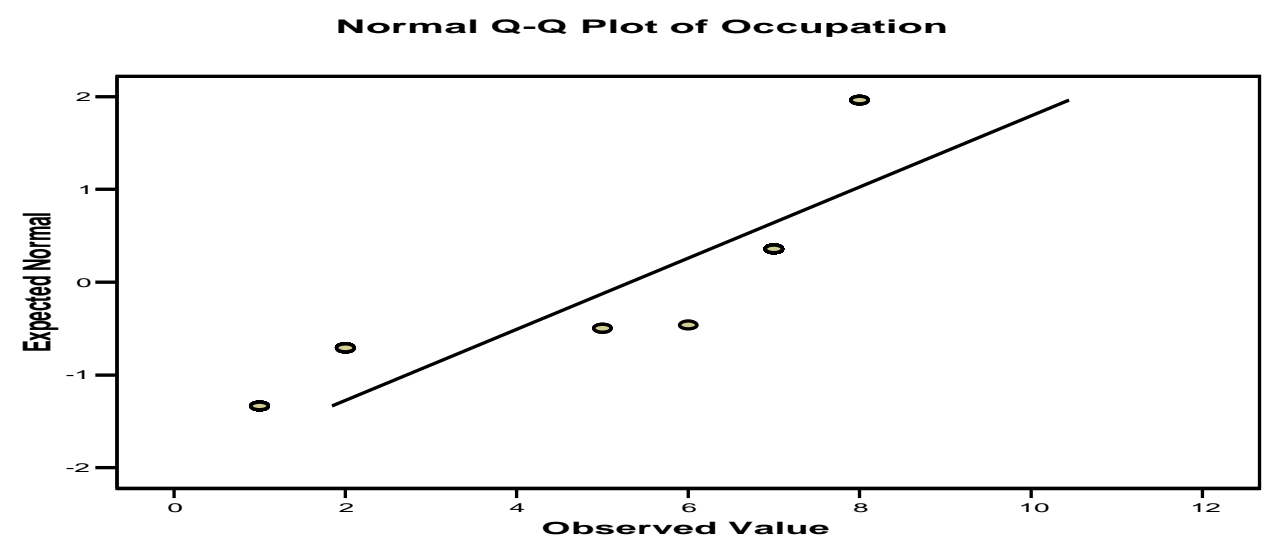

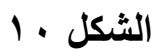

نسبة وقوع المشاهدات على خط مستقيم

ع. كما يمكن ملاحظة الشكل /ل و الذي يعطي رسما للمدرج التكر اري للبيانات، وكذللك

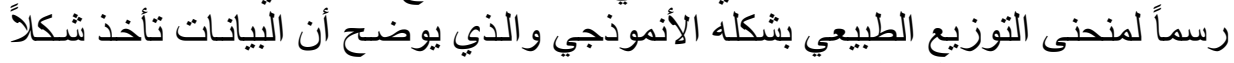
غير ناقوسي، مما يدل على عدم عودتها إلى مجتمع يعود إلى التوزيع الطبيعي.

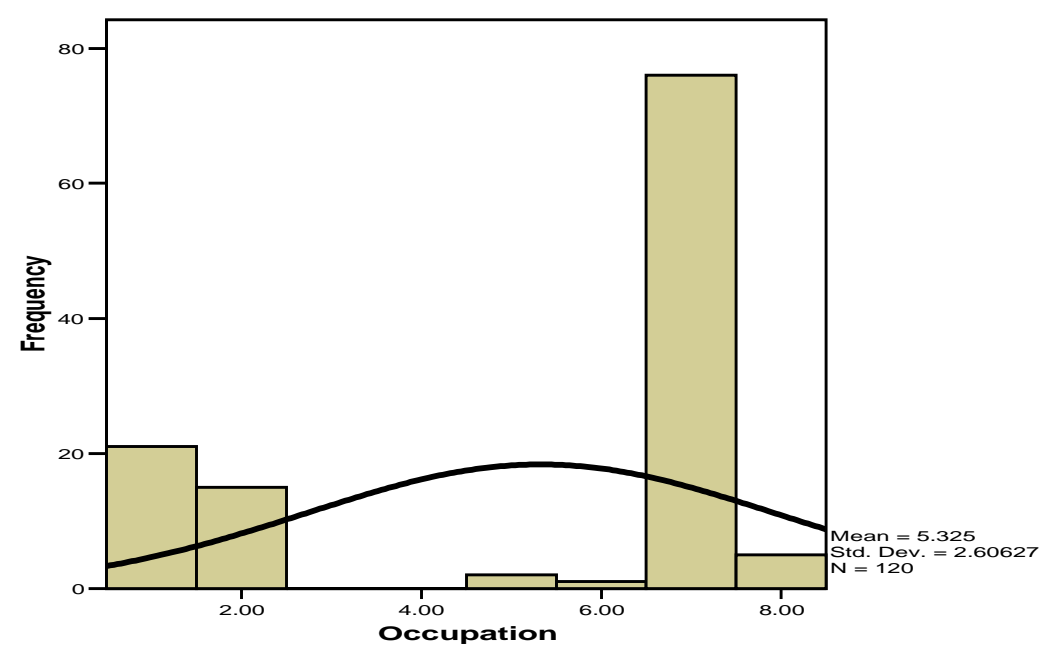

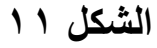

المدرج التكراري للبيانات ورسماً لمنحنى التوزيع الطبيعي بشكله الأنموذجي

خامساً تحديد معامل الارتباط بين المتغيرات التتبوئية

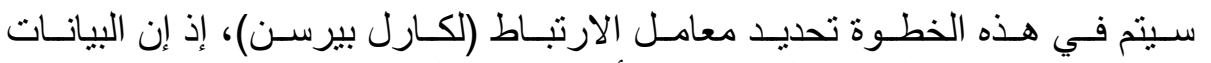

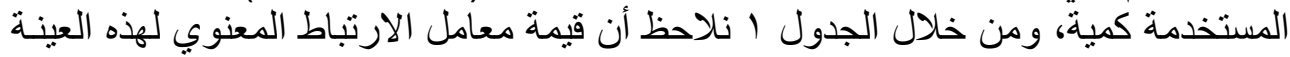

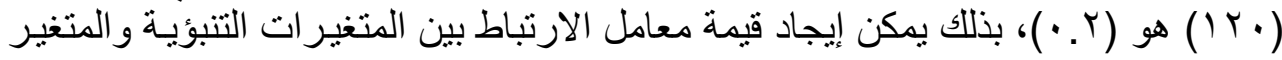




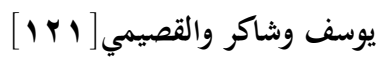

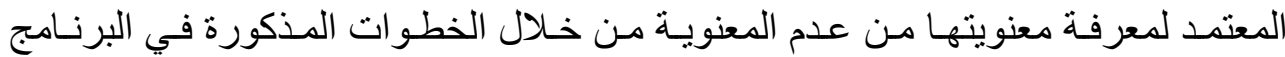
الجاهز (SPSS) الموضح في الفقرة (ץ) من ثانيا للمحور الأول وكما يأتي:

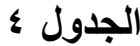 \\ معامل الارتباط بين المتفيرات التتبؤية}

Correlations

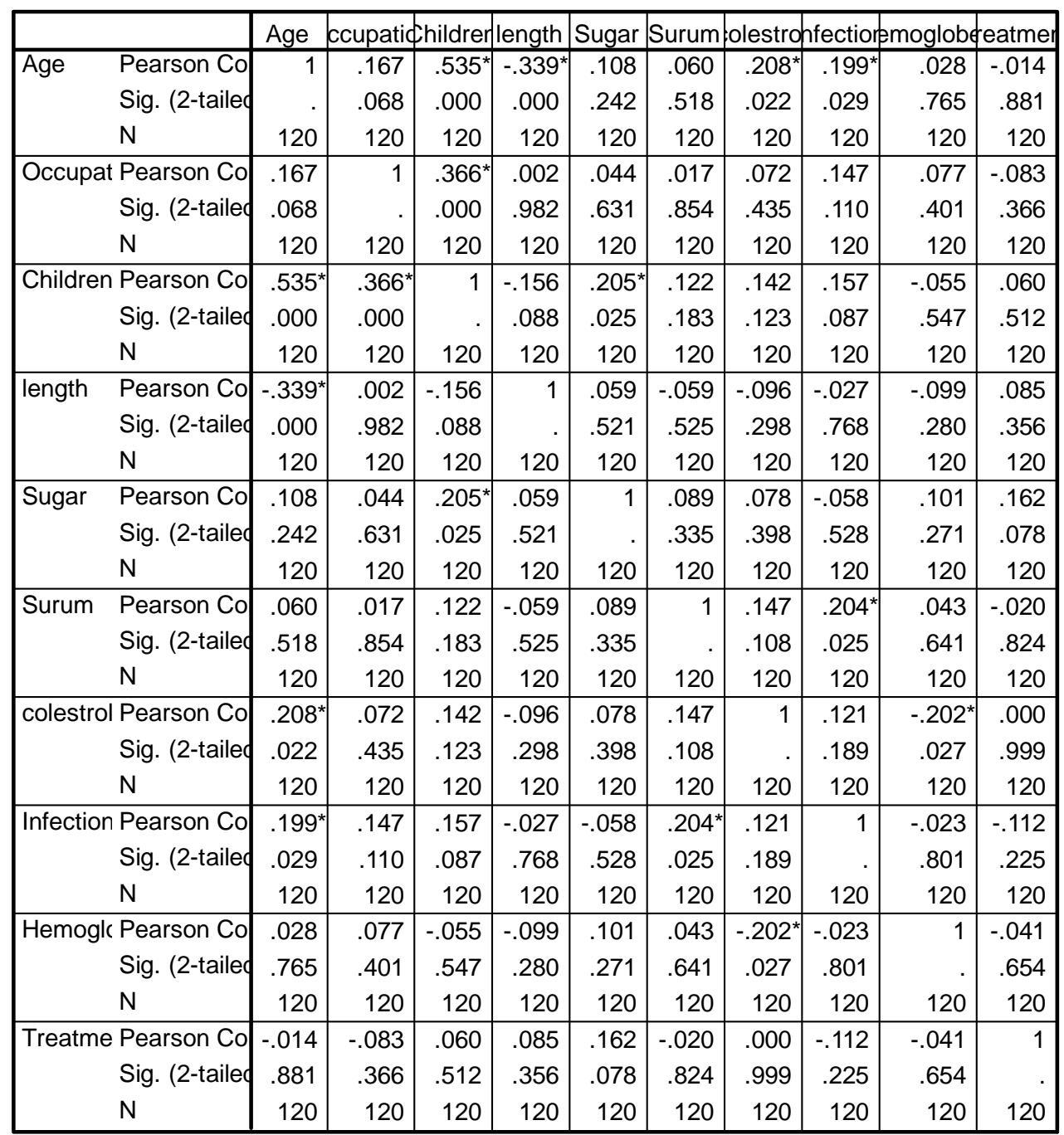

${ }^{* *}$ Correlation is significant at the 0.01 level (2-tailed).

${ }^{*}$ Correlation is significant at the 0.05 level (2-tailed).

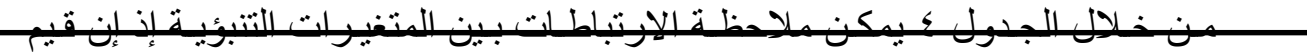

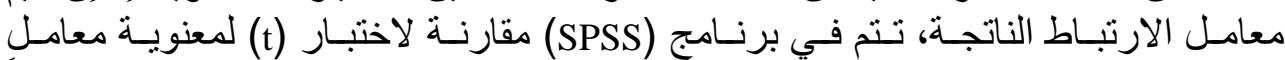

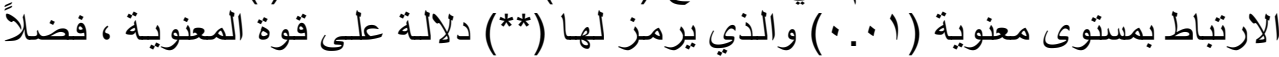

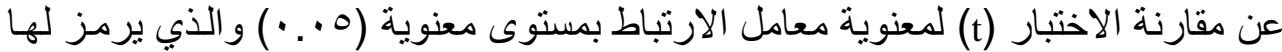




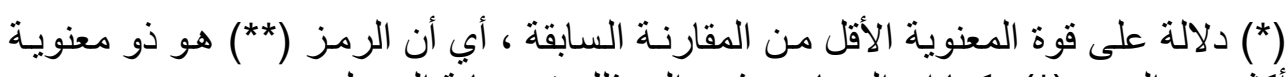
أكثر من الرمز (*)، كما إن البرنامج يثير إلى ذلك في نهاية الجدول.

سادساً تحويل البيانات إلى الصيغة القياسية

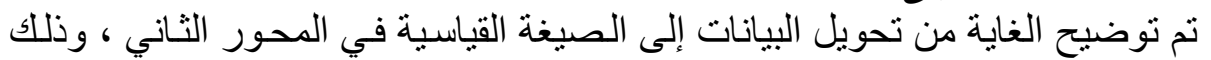

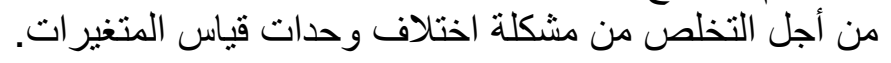

سابعاً استخراج التكرارات والنسب المئوية التية

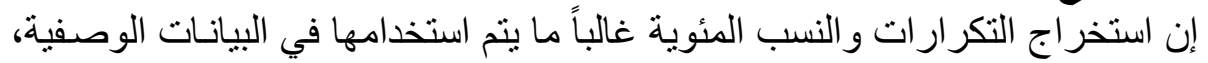

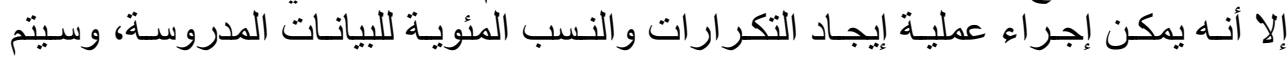

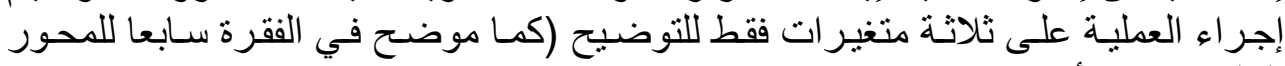

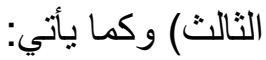

\begin{tabular}{|c|c|c|c|c|}
\hline \multicolumn{5}{|c|}{ الجدول • } \\
\hline \multicolumn{5}{|c|}{ Frequencies } \\
\hline \multicolumn{5}{|c|}{ Statistics } \\
\hline & VAR00003 & VAR00004 & VAR00011 & \\
\hline $\begin{array}{|ll|}\text { N } & \text { Valid } \\
& \text { Missing } \\
\end{array}$ & $\begin{array}{r}120 \\
0 \\
\end{array}$ & $\begin{array}{r}120 \\
0 \\
\end{array}$ & $\begin{array}{r}120 \\
0 \\
\end{array}$ & \\
\hline \multicolumn{5}{|c|}{ Frequency Table } \\
\hline & & VAROO003 & & \\
\hline & Frequency & Percent & Valid Percent & $\begin{array}{c}\text { Cumulative } \\
\text { Percent }\end{array}$ \\
\hline $\begin{array}{ll}\text { Valid } & 1.00 \\
& 2.00 \\
& 5.00 \\
6.00 \\
\\
7.00 \\
8.00 \\
\\
\text { Total } \\
\end{array}$ & $\begin{array}{r}21 \\
15 \\
2 \\
1 \\
76 \\
5 \\
120 \\
\end{array}$ & $\begin{array}{r}17.5 \\
12.5 \\
1.7 \\
8 \\
63.3 \\
4.2 \\
40.0 \\
100.0 \\
\end{array}$ & $\begin{array}{r}17.5 \\
12.5 \\
1.7 \\
.8 \\
63.3 \\
4.2 \\
100.0 \\
\end{array}$ & $\begin{array}{r}17.5 \\
30.0 \\
31.7 \\
32.5 \\
95.8 \\
100.0\end{array}$ \\
\hline
\end{tabular}

\section{الجدول المغيرين}

التكرارات والنسب المئوية للمتغيرين الرابع والحادي عثر 


\section{يوسف وشاكر والقصيمي[r r r]}

\begin{tabular}{|c|c|c|c|c|c|}
\hline \multicolumn{6}{|c|}{ VAROOOO4 } \\
\hline & & Frequency & Percent & Valid Percent & $\begin{array}{c}\text { Cumulative } \\
\text { Percent }\end{array}$ \\
\hline \multirow[t]{15}{*}{ valid } & .00 & 11 & 9.2 & 9.2 & 9.2 \\
\hline & 1.00 & 9 & 7.5 & 7.5 & 16.7 \\
\hline & 2.00 & 20 & 16.7 & 16.7 & 33.3 \\
\hline & 3.00 & 22 & $18 \cdot 3$ & 18.3 & 51.7 \\
\hline & 4.00 & 13 & 10.8 & 10.8 & 62.5 \\
\hline & 5.00 & 13 & 10.8 & 10.8 & 73.3 \\
\hline & 6.00 & 12 & 10.0 & 10.0 & 83.3 \\
\hline & 7.00 & 7 & 5.8 & 5.8 & 89.2 \\
\hline & 8.00 & 4 & 3.3 & 3.3 & 92.5 \\
\hline & 9.00 & 2 & 1.7 & 1.7 & 94.2 \\
\hline & 10.00 & 3 & 2.5 & 2.5 & 96.7 \\
\hline & 11.00 & 2 & 1.7 & 1.7 & 98.3 \\
\hline & 12.00 & 1 & 8 & 8 & 99.2 \\
\hline & 14.00 & 1 & 8 & 8 & 100.0 \\
\hline & Total & 120 & 100.0 & 100.0 & \\
\hline \multicolumn{6}{|c|}{ VAROOOO11 } \\
\hline \multirow{6}{*}{ Valid } & & Frequency & Percent & Valid Percent & $\begin{array}{c}\text { Cumulative } \\
\text { Percent }\end{array}$ \\
\hline & 500.00 & & & & \\
\hline & $\begin{array}{l}800.00 \\
900.00\end{array}$ & $\begin{array}{r}107 \\
7\end{array}$ & $\begin{array}{r}89.2 \\
5.8\end{array}$ & $\begin{array}{r}89.2 \\
5.8\end{array}$ & $\begin{array}{l}90.0 \\
95.8\end{array}$ \\
\hline & 1000.00 & & & & 96.7 \\
\hline & 1200.00 & 4 & $3 \cdot 3$ & 3.3 & 100.0 \\
\hline & Total & 120 & 100.0 & 100.0 & \\
\hline
\end{tabular}

$$
\begin{aligned}
& \text { ثامناً إيجاد الوصف الإحصائي } \\
& \text { كما تم توضيح الوصف الإحصائي الإحصائي للبيانات في الفقرة (ثامناً للمحور الثالث) يمكن } \\
& \text { إجر اء ذلك للبيانات المختارة و وعلى النحو الآتي: }
\end{aligned}
$$

\begin{tabular}{|c|c|c|c|c|c|}
\hline \multicolumn{6}{|c|}{ Descriptive Statistics } \\
\hline & $N$ & Minimum & Maximum & Mean & Std. Deviation \\
\hline VAR00002 & 120 & 23.00 & 60.00 & 38.1667 & 8.64844 \\
\hline VAR00003 & 120 & 1.00 & 8.00 & 5.3250 & 2.60627 \\
\hline VAR00004 & 120 & .00 & 14.00 & 4.0083 & 2.85061 \\
\hline VAR00005 & 120 & 141.00 & 171.00 & 157.9292 & 5.73552 \\
\hline VAR00006 & 120 & 67.00 & 240.00 & 90.7417 & 27.68414 \\
\hline VAR00007 & 120 & 2.40 & 7.20 & 4.0342 & .92750 \\
\hline VAR00008 & 120 & 110.00 & 330.00 & 197.9250 & 33.27784 \\
\hline VAROO009 & 120 & 1.00 & 45.00 & 10.4333 & 9.51490 \\
\hline VAR00010 & 120 & 72.00 & 110.00 & 87.7750 & 7.69313 \\
\hline VAR00011 & 120 & 500.00 & 1200.00 & 818.3333 & 81.97492 \\
\hline Valid N (listwise) & 120 & & & & \\
\hline
\end{tabular}

تاسعاً. إجراء تحليل الاتحدار وإيجاد معامل التحديد

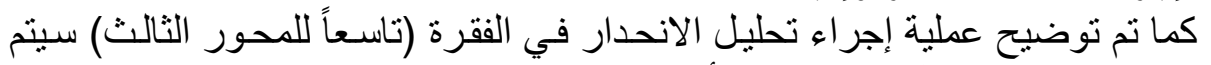
تطبيق ذلك على البيانات المختارة وكما يأتي: 
قيمة معامل التحديد

Model Summary

\begin{tabular}{|l|r|r|r|c|}
\hline Model & $\mathrm{R}$ & $\mathrm{R}$ Square & $\begin{array}{c}\text { Adjusted } \\
\text { R Square }\end{array}$ & $\begin{array}{c}\text { Std. Error of } \\
\text { the Estimate }\end{array}$ \\
\hline 1 & $.563^{\mathrm{a}}$ & .317 & .255 & 15.17593 \\
\hline
\end{tabular}

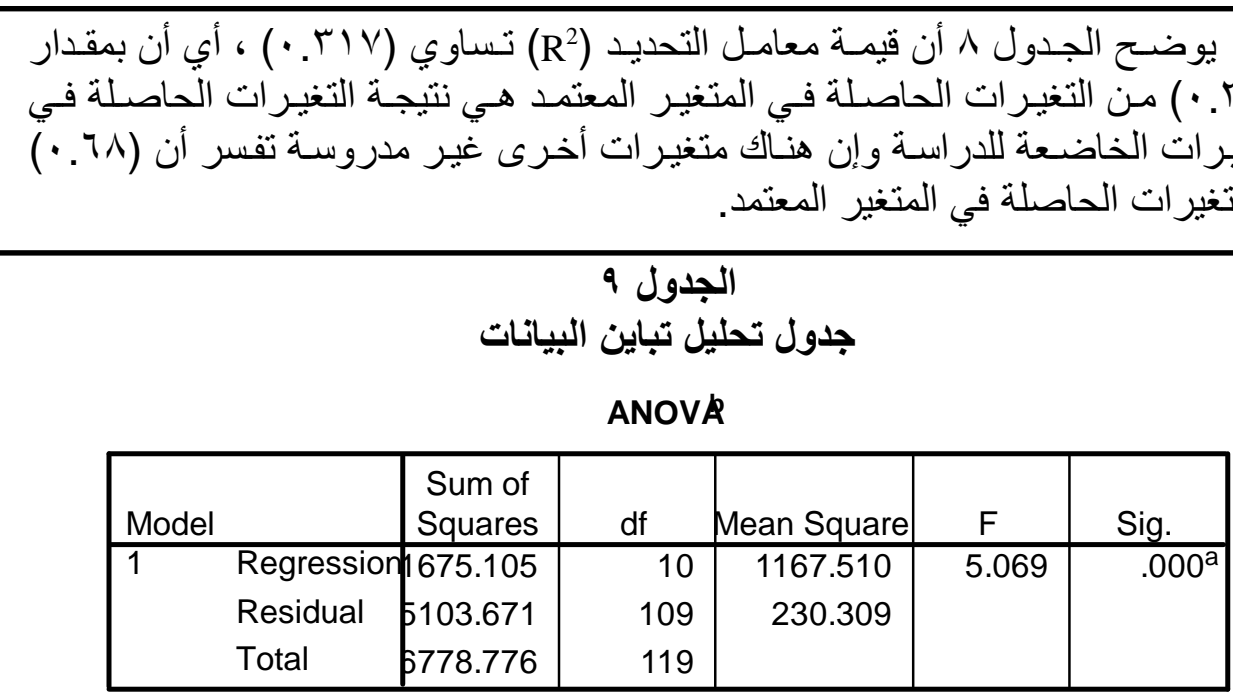

a. Predictors: (Constant), VAR00011, VAR00008, VAR00003, VAR00005, VAR00006, VAR00009, VAR00010, VAR00002, VAR00004

b. Dependent Variable: VAR00001

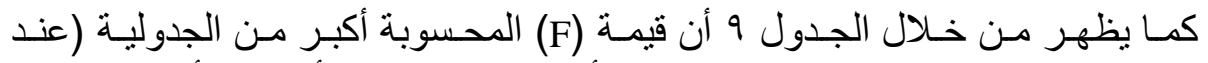

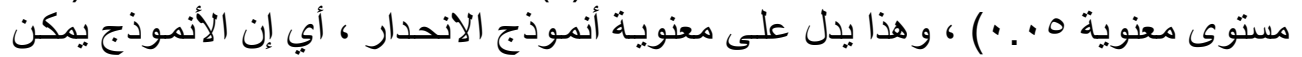

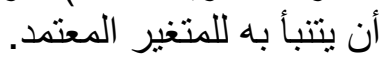
الجدول • إيبين معاملات الانحدار وكما يأتي:

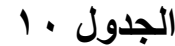

معاملات الانحدار للبيانات المختارة 


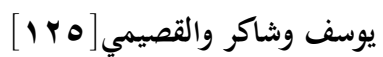

Coefficients $\mathbf{a}^{\mathrm{a}}$

\begin{tabular}{|c|c|c|c|c|c|c|c|c|}
\hline \multirow{2}{*}{\multicolumn{2}{|c|}{ Model }} & \multicolumn{2}{|c|}{$\begin{array}{c}\text { Unstandardized } \\
\text { Coefficients }\end{array}$} & \multirow{2}{*}{$\begin{array}{c}\begin{array}{c}\text { Standardized } \\
\text { Coefficients }\end{array} \\
\text { Beta }\end{array}$} & \multirow[b]{2}{*}{$t$} & \multirow[b]{2}{*}{ Sig. } & \multicolumn{2}{|c|}{ Collinearity Statistics } \\
\hline & & $\mathrm{B}$ & Std. Error & & & & Tolerance & VIF \\
\hline \multirow[t]{11}{*}{1} & (Constant) & -78.903 & 51.387 & & -1.535 & .128 & & \\
\hline & VAR00002 & .080 & .205 & .040 & .391 & .696 & .615 & 1.627 \\
\hline & VAR00003 & 1.338 & .587 & .198 & 2.277 & .025 & .826 & 1.211 \\
\hline & VAR00004 & 1.883 & .635 & .305 & 2.968 & .004 & .591 & 1.691 \\
\hline & VAR00005 & .996 & .263 & .325 & 3.783 & .000 & .849 & 1.177 \\
\hline & VAR00006 & .001 & .053 & .002 & .023 & .982 & .893 & 1.120 \\
\hline & VAR00007 & -1.298 & 1.566 & -.068 & -.829 & .409 & .918 & 1.090 \\
\hline & VAR00008 & .060 & .045 & .113 & 1.340 & .183 & .879 & 1.137 \\
\hline & VAR00009 & .119 & .155 & .064 & .764 & .446 & .886 & 1.129 \\
\hline & VAR00010 & .220 & .191 & .096 & 1.154 & .251 & .898 & 1.114 \\
\hline & VAR00011 & -.039 & .017 & -.181 & -2.217 & .029 & .942 & 1.062 \\
\hline
\end{tabular}

a. Dependent Variable: VAR00001

$$
\text { بذلك تكون معادلة الانحدار كما يأتي: }
$$

$y=-78.9+0.08 \times 1+1.338 \times 2+1.883 \times 3+0.996 \times 4+0.001 \times 5-1.298 \times 6+0.06 \times 6$

$$
+0.119 \times 7+0.22 \times 8-0.039 \times 9
$$

\section{عاشـراً. التذاخل الخطي}

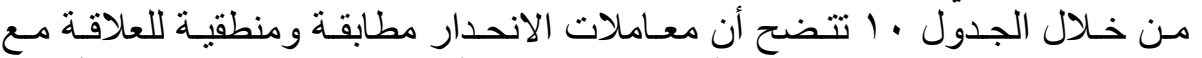

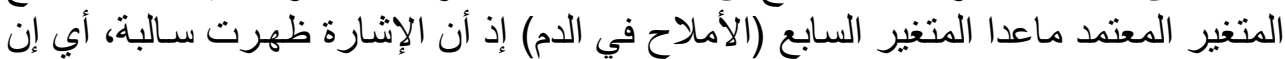

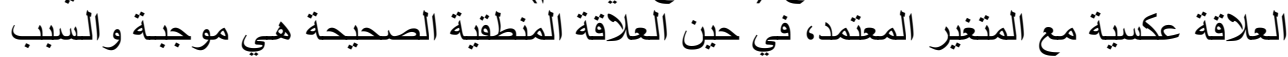

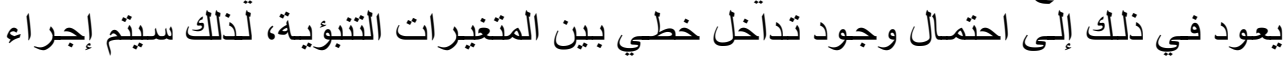

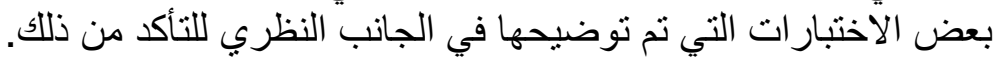

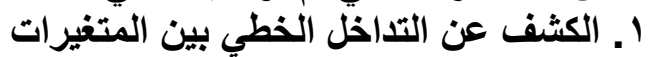

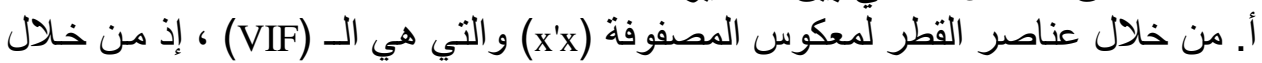

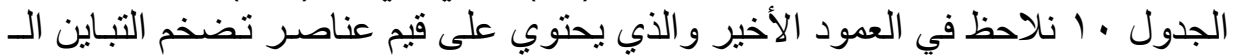

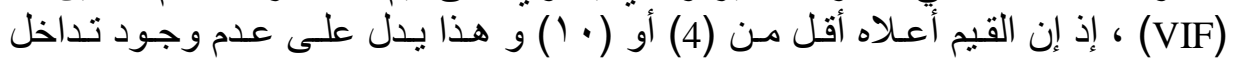

$$
\text { خطي بين المتغير ات الت التنبؤية. }
$$

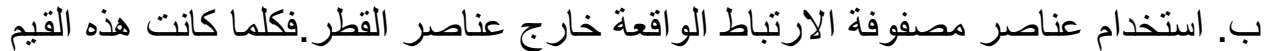

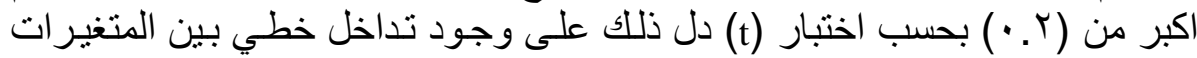

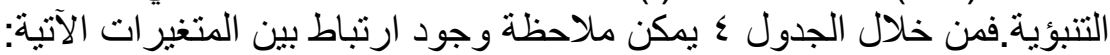

$\begin{array}{rrrr}\text { X3,X4 } & \text { X2,X8 } & \text { X2,X5 } & \text { X2,X4 } \\ \text { X8,X10 } & \text { X7,X9 } & \text { X7,X8 } & \text { X4,X6 }\end{array}$

ج. من خلال الثكل الانتشاري: سيتم رسم الثكل الانتشاري لبعض المتغير ات للتناكد من وجود التداخل الخطي بين المنغير ات وكما يأتي: 


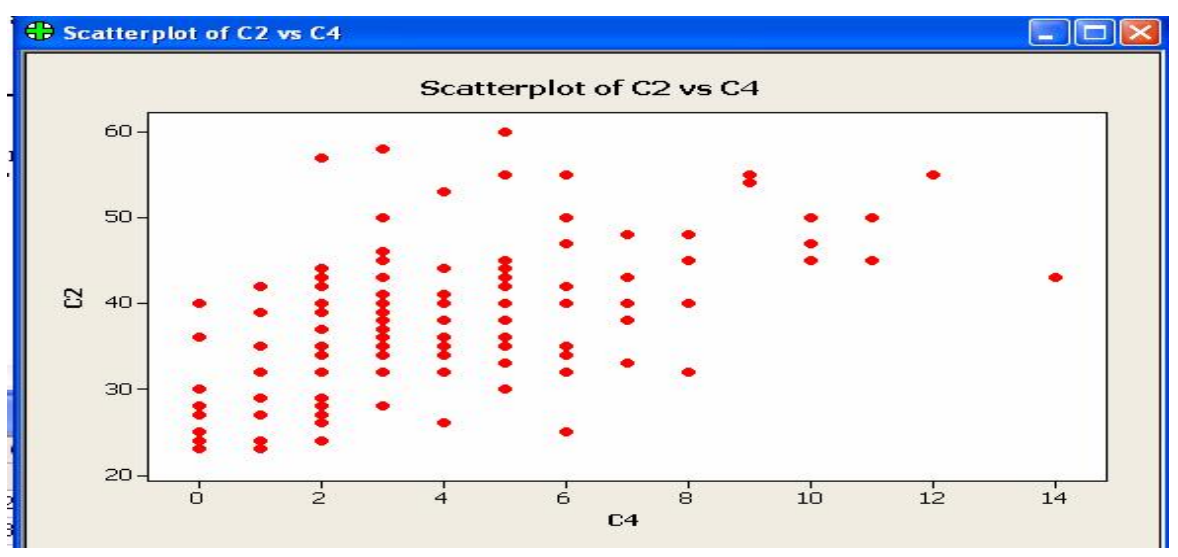

$$
\begin{aligned}
& \text { الثكل با با } \\
& \text { الرسم الانتثاري بين المتغيرين الثاني والرابع }
\end{aligned}
$$

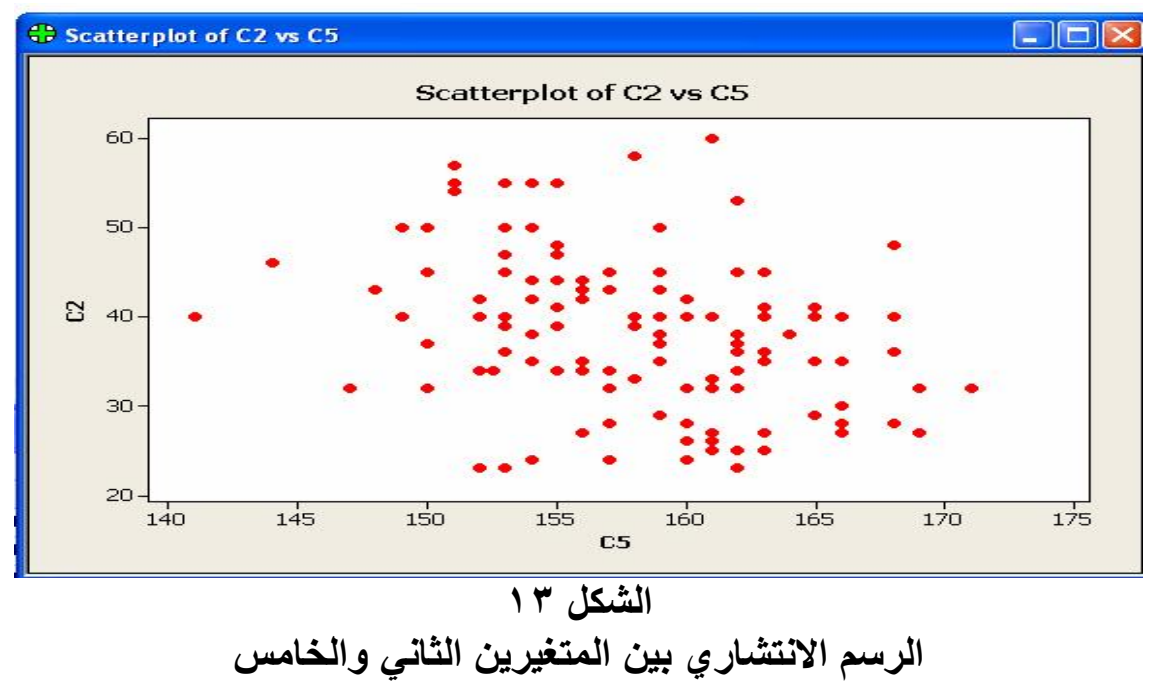

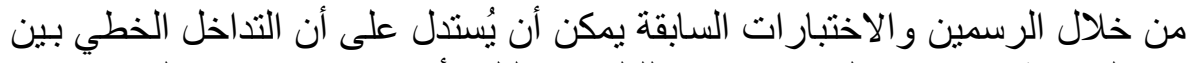

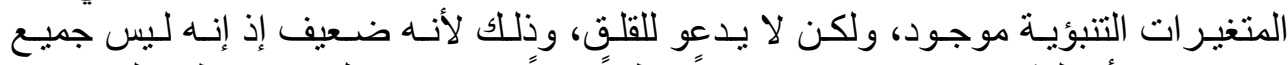

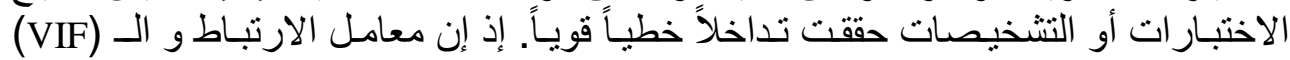
هما فقط اللذان الذين حققا وبضعف وجود تداخل خطي، أما الرسم الانتشاري فلم يحقق الأن ذلك.

بذلك لا بستلزم تطبيق الطر ائق المتحيزة للتخلص من التداخل الخطي الموجود بين المتغير ات التنبؤية ، و إنما يتم الاعتماد على معادلة الانحدار ( ) للتنبؤ.

المحور الرابع- الجانب العملي 


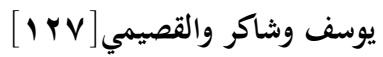

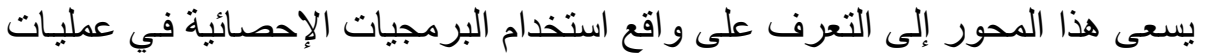
التحليل المتبعة من قبل الباحثين، واستنادا إلى ذلك فقد تم التحقق من ذلك بـاللجوء التح لتحليل

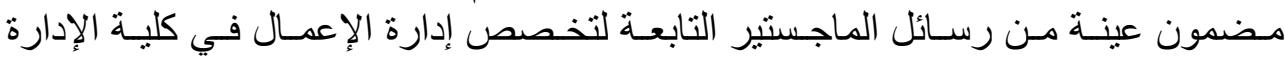

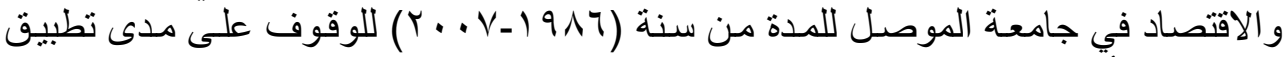

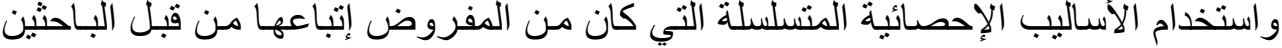

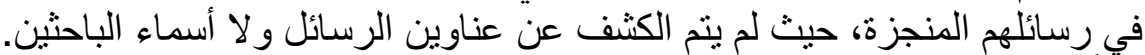

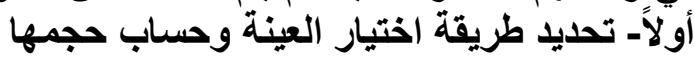

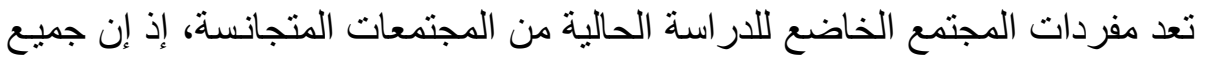

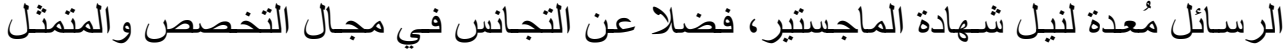

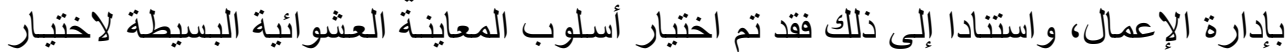

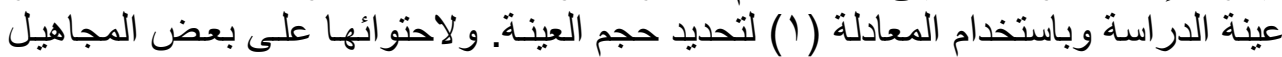

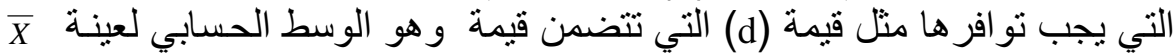

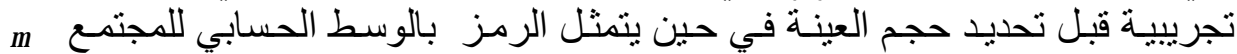

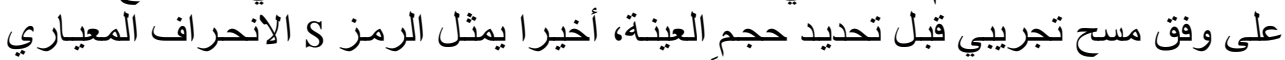

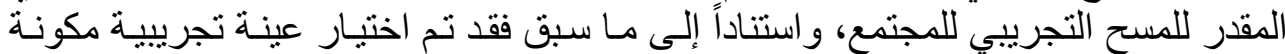

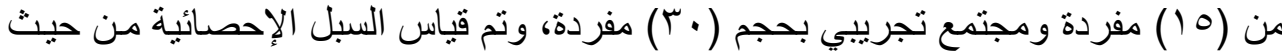

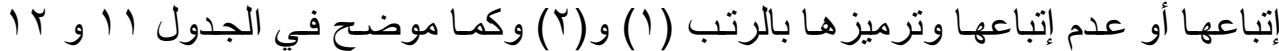
التاليين: - n

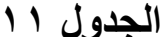

الرتب المعطاة للأساليب الإحصائية من حيث الاستخدام أو عدم الاستخدام

\begin{tabular}{|c|c|c|c|}
\hline الرتبة & حالات الاستخدام & الأسلوب الإحصائي & ت \\
\hline 1 & أسلوب علمي & \multirow{2}{*}{ تحديد حجم العينة } & \multirow{2}{*}{1} \\
\hline r & أسلوب غير علمي & & \\
\hline 1 & تم إيجاده & \multirow{2}{*}{ إيجاد معامل ألفا كرومباخ } & \multirow{2}{*}{ r } \\
\hline r & لم يتم إيجاده & & \\
\hline 1 & تم الاختبار & \multirow{2}{*}{ التوزيع الطبيعي عودة البيانات إلى مجتمع يعود إلى } & \multirow{2}{*}{ r } \\
\hline$r$ & لم يتم الاختبار & & \\
\hline$\overline{1}$ & كارل بيرسن & \multirow{2}{*}{ نوع معامل الارتباط المستخدم } & \multirow{2}{*}{$\varepsilon$} \\
\hline$r$ & سبيرمان & & \\
\hline 1 & تم التحديد & \multirow{2}{*}{ تحديد قيمة معامل الارتباط } & \multirow{2}{*}{0} \\
\hline$r$ & لم يتم التحديد & & \\
\hline 1 & تم التشخيص & \multirow{2}{*}{ تشخيص التذاخل الخطي } & \multirow{2}{*}{7} \\
\hline$r$ & لم يتم التشخيص & & \\
\hline 1 & تم اعتماده & \multirow{2}{*}{ اعتماد معامل التحديد R } & \multirow{2}{*}{$\checkmark$} \\
\hline$r$ & لم يتم اعتماده & & \\
\hline
\end{tabular}

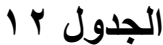

مسحاً تجريبياً من مجتمع الدراسة لتحديد حجم العينة 


\begin{tabular}{|c|c|c|c|c|c|c|c|}
\hline اعتماد R & تشخيص التذاخل & قيمة تحديل & نوع معامل & للتيانيات الطوديع & أيجاد & حجم & التسلسل \\
\hline 1 & $r$ & $r$ & 1 & $r$ & $r$ & $r$ & 1 \\
\hline$r$ & $r$ & $r$ & 1 & $r$ & 1 & 1 & $r$ \\
\hline$r$ & $r$ & $r$ & 1 & $r$ & 1 & $r$ & $r$ \\
\hline 1 & $r$ & 1 & 1 & 1 & 1 & $r$ & $\varepsilon$ \\
\hline 1 & $r$ & 1 & 1 & $r$ & 1 & 1 & 0 \\
\hline 1 & $r$ & $T$ & $r$ & $r$ & 1 & $r$ & 7 \\
\hline$r$ & $r$ & 1 & 1 & $r$ & 1 & $r$ & V \\
\hline$r$ & $r$ & $T$ & 1 & $r$ & 1 & $r$ & $\Lambda$ \\
\hline$r$ & $r$ & 1 & 1 & $r$ & 1 & $r$ & 9 \\
\hline 1 & $r$ & $r$ & 1 & 1 & 1 & $r$ & 1. \\
\hline 1 & $\bar{r}$ & $r$ & 1 & $\bar{r}$ & 1 & 1 & 11 \\
\hline 1 & $r$ & $r$ & 1 & $r$ & 1 & $r$ & Ir \\
\hline 1 & $r$ & $r$ & $r$ & $r$ & 1 & $r$ & $1 T$ \\
\hline 1 & $r$ & $r$ & 1 & $r$ & 1 & $r$ & $1 \varepsilon$ \\
\hline 1 & $r$ & 1 & 1 & $r$ & $r$ & $r$ & 10 \\
\hline 1 & $r$ & $r$ & 1 & $\bar{r}$ & $r$ & $r$ & 17 \\
\hline 1 & $r$ & $r$ & 1 & $r$ & 1 & $r$ & $1 V$ \\
\hline 1 & $r$ & $r$ & 1 & 1 & 1 & r & 11 \\
\hline$r$ & $r$ & $r$ & 1 & $r$ & 1 & $r$ & 19 \\
\hline$T$ & $r$ & $\bar{r}$ & 1 & $\bar{r}$ & 1 & $\bar{r}$ & $r$. \\
\hline 1 & $r$ & 1 & 1 & $r$ & 1 & $r$ & $r I$ \\
\hline 1 & $r$ & 1 & 1 & $r$ & 1 & $\bar{r}$ & YY \\
\hline 1 & $r$ & 1 & 1 & $r$ & 1 & $r$ & $r r$ \\
\hline 1 & $r$ & 1 & 1 & $r$ & 1 & $r$ & $r \leq$ \\
\hline$r$ & $r$ & 1 & 1 & $r$ & 1 & $r$ & ro \\
\hline 1 & $\bar{r}$ & $\bar{r}$ & 1 & $\bar{r}$ & 1 & 1 & $r 7$ \\
\hline 1 & $r$ & 1 & 1 & $r$ & 1 & $r$ & $r V$ \\
\hline 1 & $\bar{r}$ & 1 & 1 & $r$ & 1 & $\bar{r}$ & $r \wedge$ \\
\hline$r$ & $r$ & 1 & 1 & $r$ & 1 & $r$ & $r q$ \\
\hline 1 & $r$ & 1 & 1 & $r$ & 1 & $r$ & $\mu$. \\
\hline
\end{tabular}

$$
\bar{X}=1.561, \mu=1.538, S=0.311, z_{c a l}(1-0.05 / 2)=1.96
$$




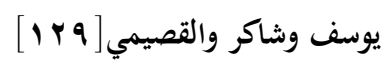

بذلك تكون قيمة n وبحسب المعادلة ( ) - كما يأتي:

$$
\begin{aligned}
& n=\left(\frac{Z S}{d}\right)^{2} \\
& \quad d=|\bar{x}-\mu|=|1.561-1.538|=0.023
\end{aligned}
$$

$$
\begin{aligned}
& n=\left(\frac{1.96 * 0.311}{0.023}\right)^{2} \\
& n=702.38
\end{aligned}
$$

و هذه القيمة أكبر من (· (1\%) من حجم المجتمع، بذلك يتم استخدام الصيغة (Y) وكما يأتي لحساب حجم العينة الذي سيعتمد:

$$
\begin{aligned}
& n=\frac{n}{1+\frac{n}{N}} \\
& n=\frac{702.38}{1+\frac{702.38}{30}}=28.7 \approx 29
\end{aligned}
$$

بذللك سيكون حجم العينة المعتمد في الدراسة هو (Y9).

$$
\text { ثانباً إيجاد نسب الإخفاق }
$$

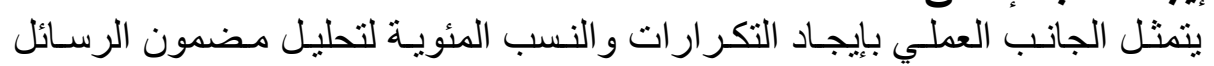

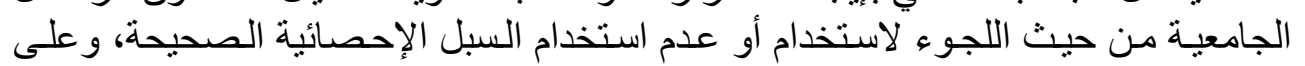
أساس السبل والإجراءات الإحصائية اللازم إتباعها قبل وبعد الحصول الإنب على البيانات.

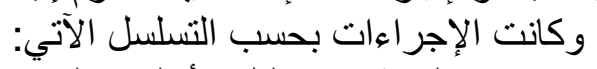

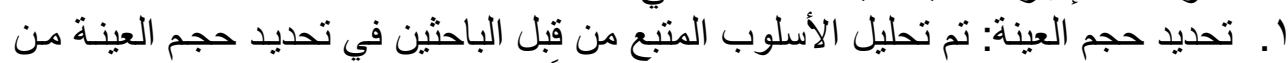

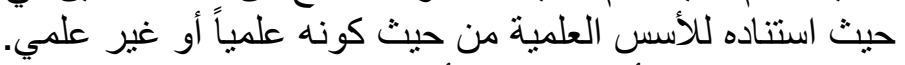

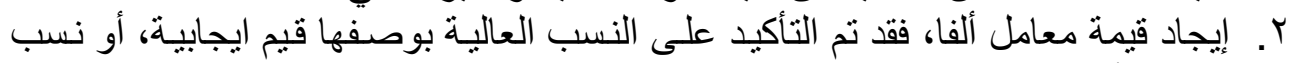
ضعيفة أو لم يتم إيجاده. r. اختبار عودة البيانات إلى مجتمع يعود إلى التوزيع الطبيعي من حيث تم إجراء الاختبار

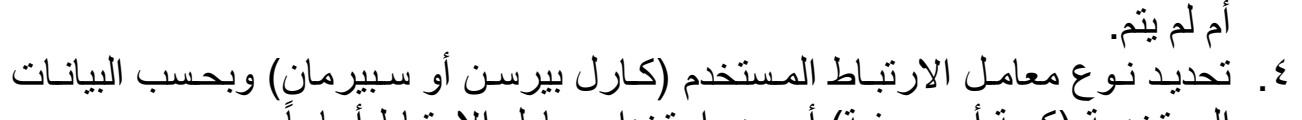
المستخدمة (كمية أو وصفية) أو الو عدم استخدام معامل الارتباط أسباساً. 
ه. تحديد قيمة معامل الارتباط بمـا يتناسب وحجم العينـة من حيث مـا تم تحديده من قبل الباحثين أم لم يتم تحديده.

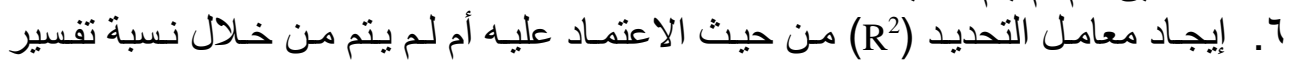
المتغير ات المدروسة على التهل متغير الاستجابة.

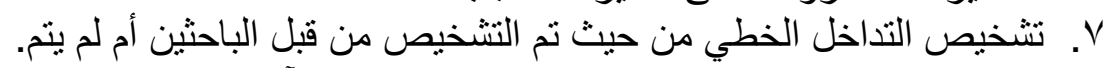
وكانت حصيلة در اسة العينة موضحة حئ في الجدول الآتي:

\begin{tabular}{|c|c|c|c|c|c|}
\hline \multicolumn{6}{|c|}{ 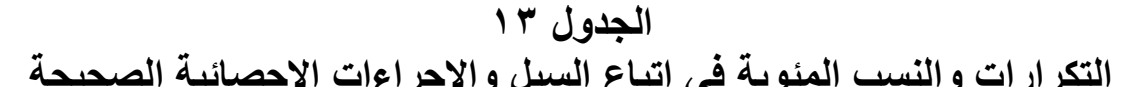 } \\
\hline النسيب & التكر ار ات & \multicolumn{2}{|c|}{ تحديد الإجراء } & السبل و الإجر اءات & ت تسلسل \\
\hline $1 \pi .1$ & $\varepsilon$ & \multicolumn{2}{|l|}{ علمي } & \multirow{2}{*}{ تحديد حجم العينة } & \multirow{2}{*}{1} \\
\hline$\wedge \neg . r$ & ro & \multicolumn{2}{|c|}{ غير علمي } & & \\
\hline - & $\cdot$ & التأكد من السؤال & \multirow{3}{*}{ تم إيجاده } & \multirow{4}{*}{ إيجاد معامل ألفا } & \multirow{4}{*}{ r } \\
\hline Vq.r & Tr & نسبة ألفا عالية & & & \\
\hline $1 \cdot . r$ & $r$ & نسبة ألفا ضعيفة & & & \\
\hline $1 \cdot . r$ & $r$ & \multicolumn{2}{|c|}{ لم يتم إيجاده } & & \\
\hline $1 \cdot . r$ & $r$ & \multicolumn{2}{|c|}{ تم الاختبار } & \multirow{2}{*}{ اختبار عودة البيانات } & \multirow{2}{*}{ r } \\
\hline $19 . \mathrm{V}$ & ry & \multicolumn{2}{|c|}{ لم يتم الاختبار } & & \\
\hline - & - & بيرسن & \multirow{3}{*}{ كمية } & \multirow{6}{*}{ نوع معادل الارنباط على نوع البيانات } & \multirow{6}{*}{$\varepsilon$} \\
\hline . & - & سبيرمان & & & \\
\hline IV.Y & 0 & لم يستخدم & & & \\
\hline 01.7 & IV & بيرسن & \multirow{3}{*}{ وصفية } & & \\
\hline 7.9 & $r$ & سبيرمان & & & \\
\hline IV.r & 0 & لم يستخدم & & & \\
\hline$\varepsilon \varepsilon . \wedge$ & $1 \pi$ & \multicolumn{2}{|c|}{ تم التحديد } & \multirow{2}{*}{ تحديد قيمة معامل } & \multirow{2}{*}{0} \\
\hline 00.1 & 17 & \multicolumn{2}{|c|}{ لم يتم التحديد } & & \\
\hline$\%$. & . & \multicolumn{2}{|c|}{ تم التشخيص } & \multirow{2}{*}{ تشخيص التداخل } & \multirow{2}{*}{7} \\
\hline $1 \ldots$ & rq & \multicolumn{2}{|c|}{ لم يتم التشخيص } & & \\
\hline 79 & $r \cdot$ & \multicolumn{2}{|c|}{ تم الاعتماد } & \multirow{2}{*}{ اعتماد R } & \multirow{2}{*}{ V } \\
\hline T) & 9 & \multicolumn{2}{|c|}{ لم يتم الاعتماد } & & \\
\hline
\end{tabular}

ثنالثاً مناقشة النتائج

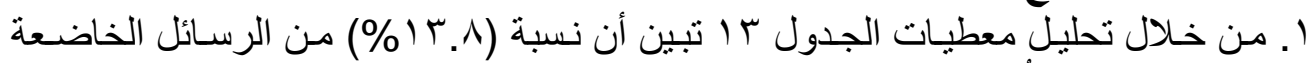

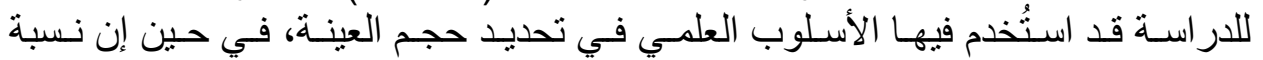

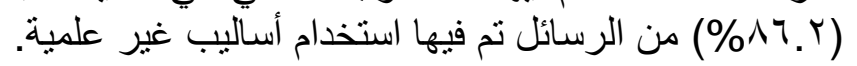


يوسف وشاكر والقصيمي[ آما']

r. أما بالنسبة إلى إيجاد معامل ألفا فكانت (7. .19\%) من الرسائل المنجزة قد أوجد فيها هذا

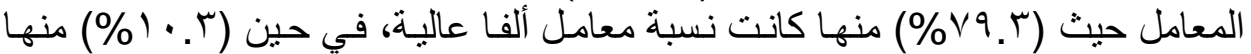

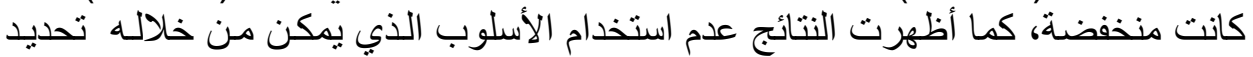
المتغير الذي يساهم في تقليل قيمة معامل ألفئ ألفا.

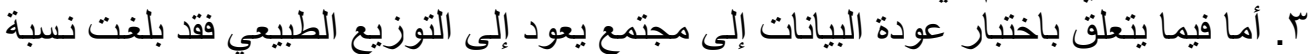

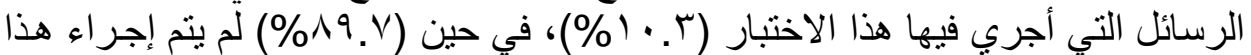

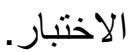

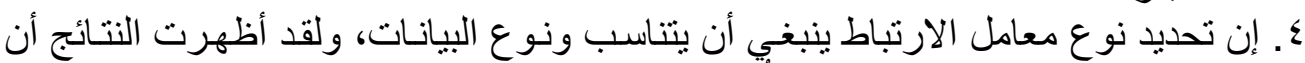

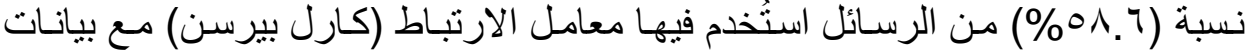

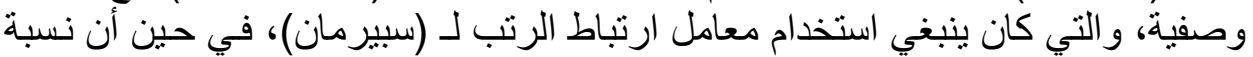

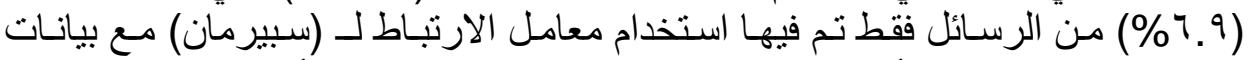

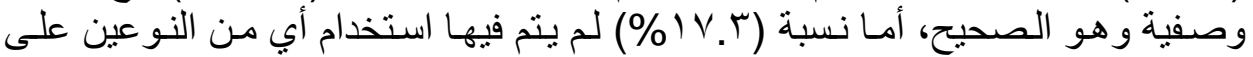

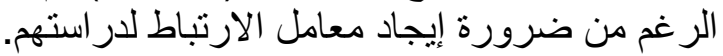

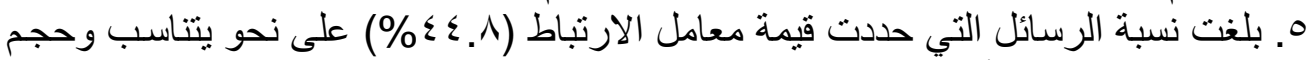

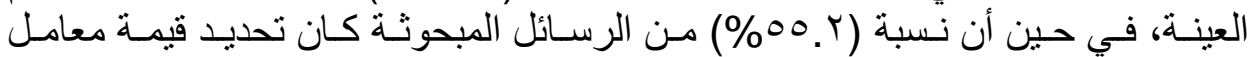

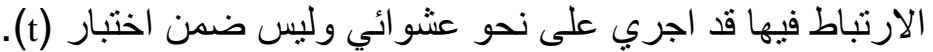

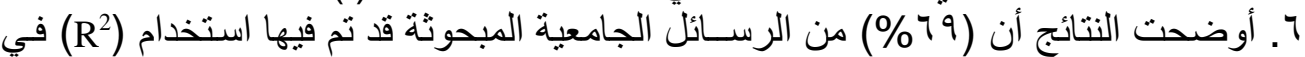

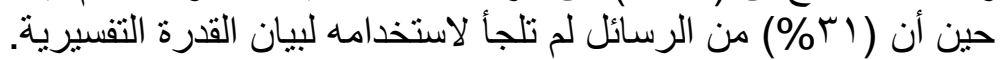

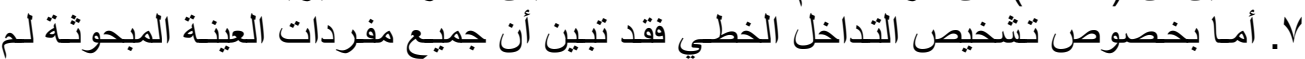

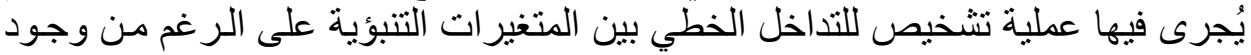
بعض المؤشرات التي توحي بوجود تداخل خطي للعديد من الرسائل الخاضعة للبحث. للنئ

الاستنتاجات

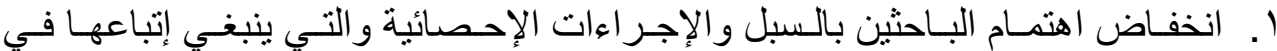

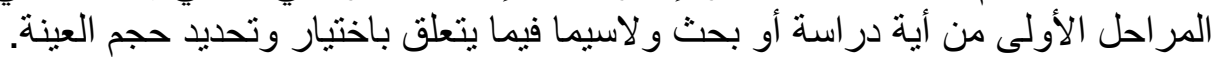

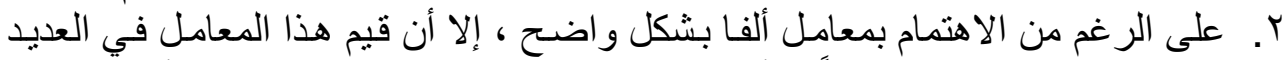

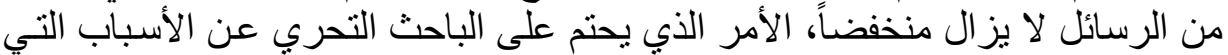
تؤدي إلى ذلك انلك.

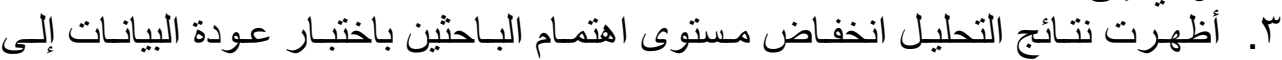

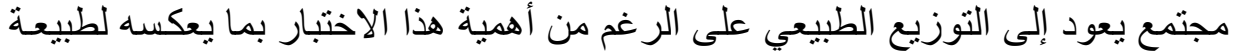
البيانات وو اقعيتها. ع. انخفاض مستوى تمييز بعض الباحثين بين أنو اع معاملات الارتباط بما يتناسب ونوع إنان

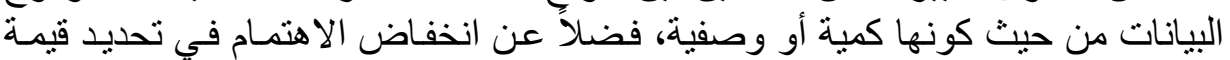

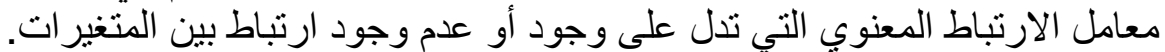

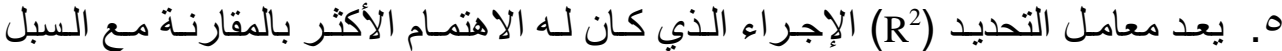

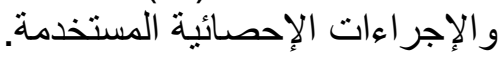

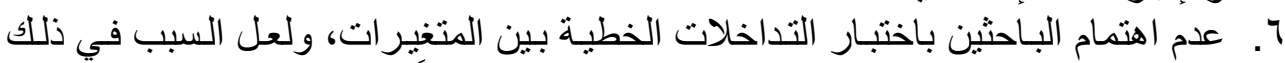

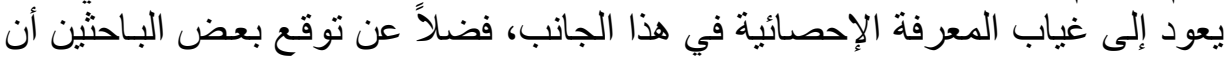
هذا الاختبار يقتصر على جو انب محددة. 
المقترحات

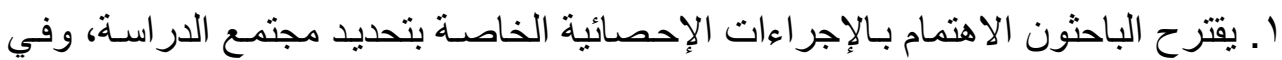

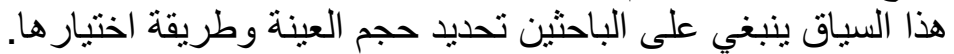

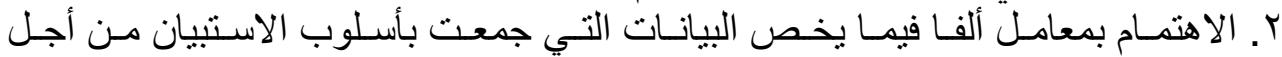

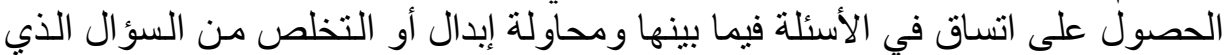
يقلل من قيمة معامل ألفاً. r. الاهتمام باختبار عودة البيانات إلى مجتمع يعود إلى الفى التوزيع الطبيعي لمـا لـه أهمية في تحديد بيانات تعود إلى الواقع العمدي.

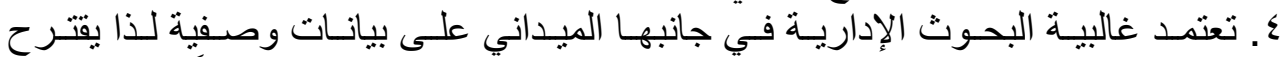

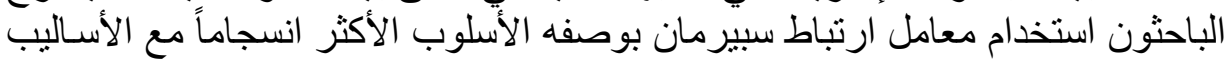
التي تتعامل مع البيانات الوصفية.

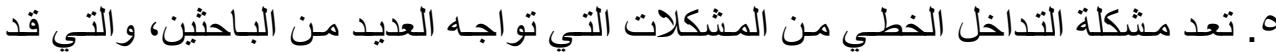

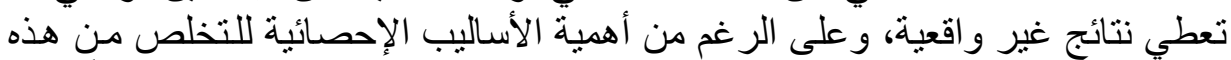

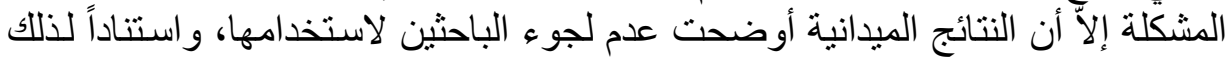

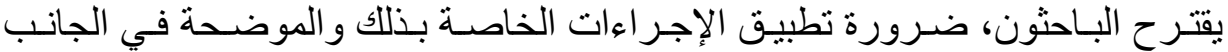

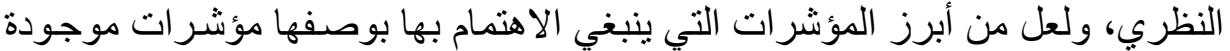

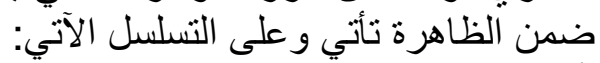

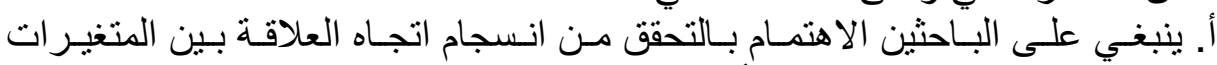

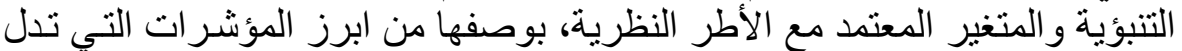
على وجود التداخلات الخطية.

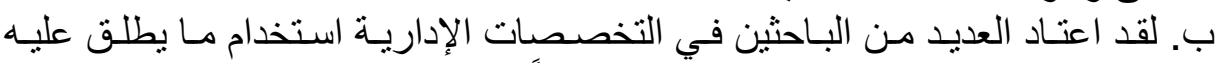

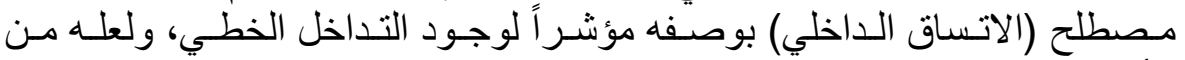

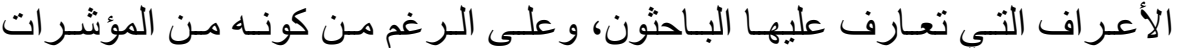

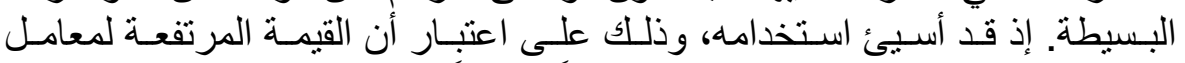

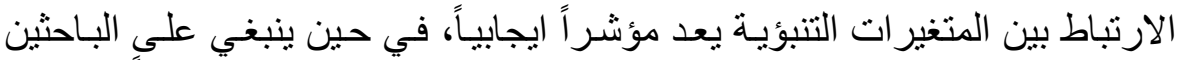

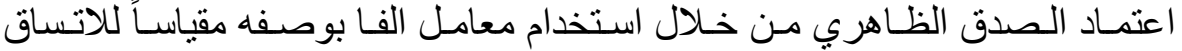

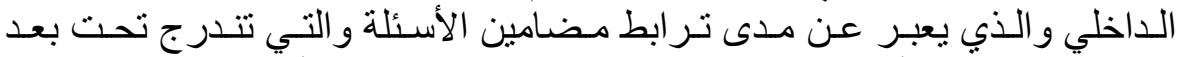

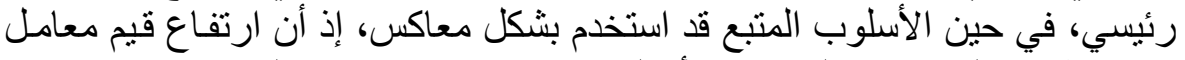

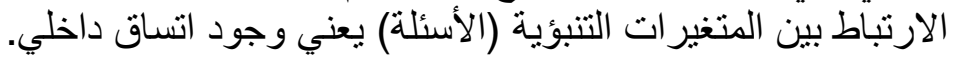

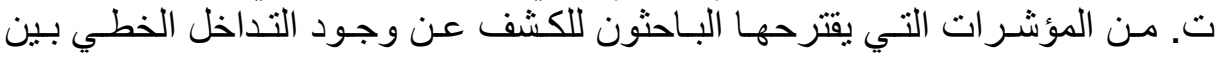

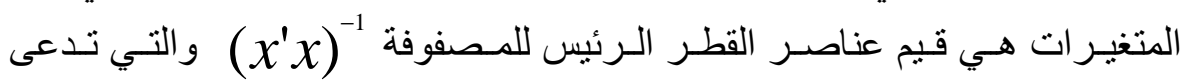
بعو امل تضخم التباين (VIF).

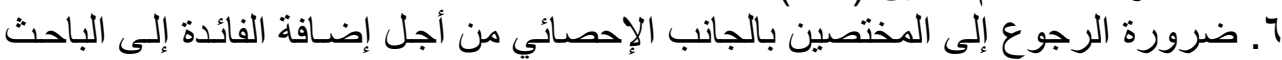

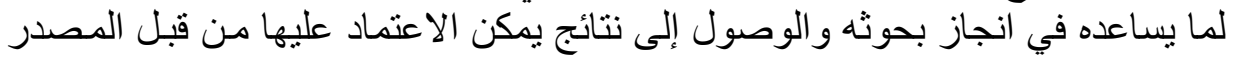
أو المجتمع الذي تم جمع البيانات منه. 


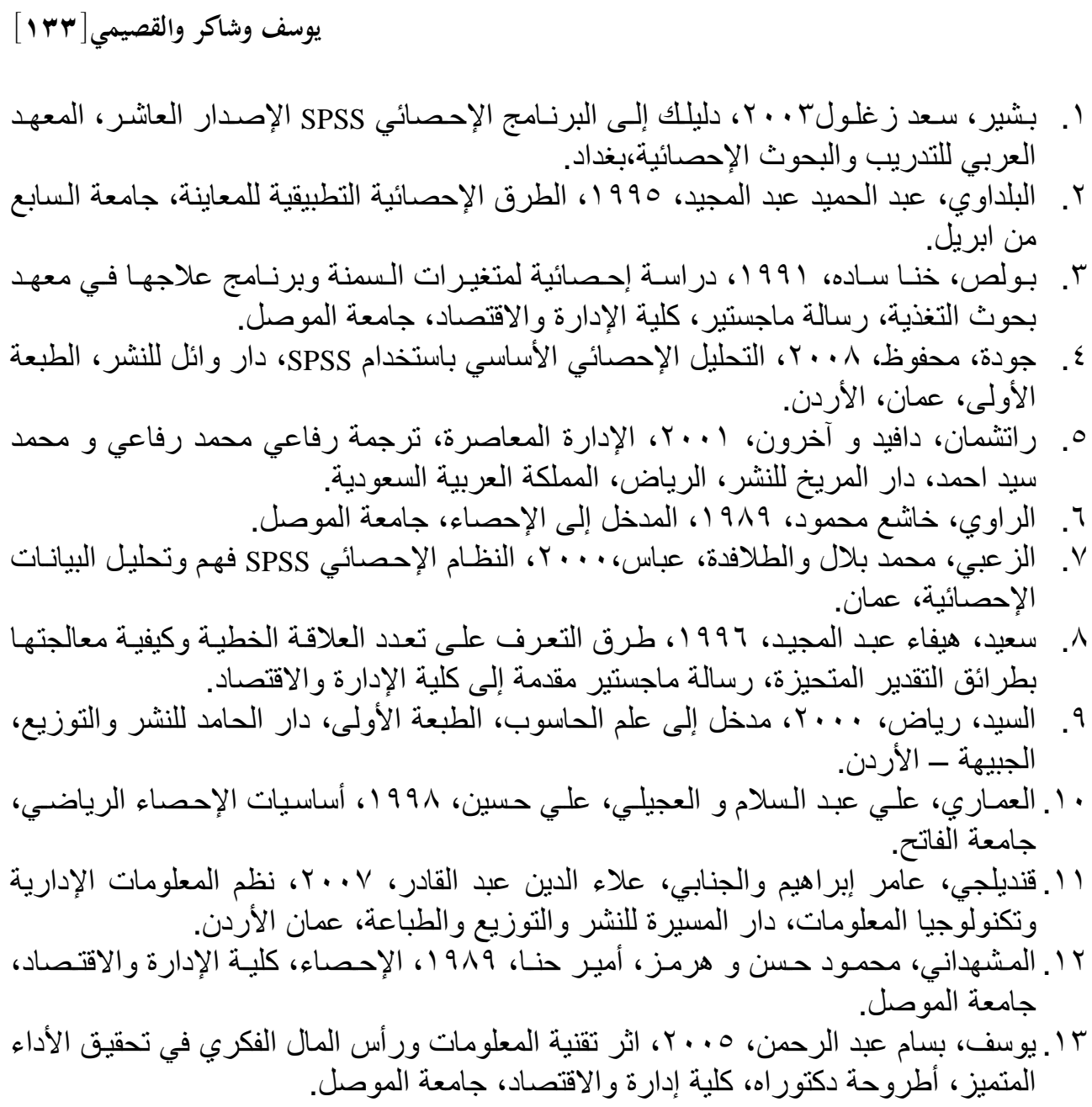

ثانياً- المراجع باللغة الأجنبية

1. Donald W. M. And Ronald D. Snee,1973. Ridge Regression in Practice, Engineering Dept., E. I. Du Pont de Nemours \& Co., Inc., Wilmington.

2. Gunst R. F. And Mason R. L.1976, Generalized Mean Squared Error Properties of Regression Estimation ,Communication of Statistics - Theory and Methods, A515.

3. Herve Abdi ,2007, The Eign - Decomposition: Eigenvalues and Eigenvectors, Encyclopedia of Measurement and Statistics. Neil Salkind ED.

4. O'Brien, James,2000,Introduction to Information Systems Essential for the Internet Worked Enterprise, $9^{\text {th }}$ edition, McGraw-Hill.

5. Ronald D. Snee,1973, Some Aspects of Nonorthogonal Data Analysis, Journal of Quality Technology. Vol. 5, No. 2.

6. Ronald D. Snee,1983,Discussion, Technometrics, Vol. 25,No. 3. 